Research paper

\title{
Characterization of free radicals by electron spin resonance spectroscopy in biochars from pyrolysis at high heating rates and at high temperatures
}

\author{
Anna Trubetskaya ${ }^{\text {a, }}{ }^{*}$, Peter Arendt Jensen a , Anker Degn Jensen a , Peter Glarborg a, \\ Flemming Hofmann Larsen ${ }^{\mathrm{b}}$, Mogens Larsen Andersen ${ }^{\mathrm{b}, * *}$ \\ ${ }^{a}$ Department of Chemical and Biochemical Engineering, Technical University of Denmark, Søltofts Plads Bygning 229, Kgs. Lyngby 2800, Denmark \\ ${ }^{\mathrm{b}}$ Department of Food Science, University of Copenhagen, Rolighedsvej 26, 1958 Copenhagen, Denmark
}

\section{A R T I C L E I N F O}

\section{Article history:}

Received 20 February 2016

Received in revised form

16 August 2016

Accepted 29 August 2016

\section{Keywords:}

Electron spin resonance spectroscopy Biomass

Char

Fast pyrolysis

Alkali

\begin{abstract}
A B S T R A C T
The concentration and type of free radicals from the decay (termination stage) of pyrolysis at slow and fast heating rates and at high temperatures (above $1000^{\circ} \mathrm{C}$ ) in biomass char have been studied. A roomtemperature electron spin resonance spectroscopy study was conducted on original wood, herbaceous biomass, holocelluloses, lignin and their chars, prepared at high temperatures in a wire mesh reactor, an entrained flow reactor, and a tubular reactor. The radical concentrations in the chars from the decay stage range up between $7 \cdot 10^{16}$ and $1.5 \cdot 10^{18}$ spins $\mathrm{g}^{-1}$. The results indicated that the biomass major constituents (cellulose, hemicellulose, lignin) had a minor effect on remaining radical concentrations compared to potassium and silica contents. The higher radical concentrations in the wheat straw chars from the decay stage of pyrolysis in the entrained flow reactor compared to the wood chars were related to the decreased mobility of potassium in the char matrix, leading to the less efficient catalytic effects of potassium on the bond-breaking and radical re-attachments. The high Si levels in the rice husk caused an increase in the char radical concentration compared to the wheat straw because the free radicals were trapped in a char consisting of a molten amorphous silica at heating rates of $10^{3}-10^{4} \mathrm{~K} \mathrm{~s}^{-1}$. The experimental electron spin resonance spectroscopy spectra were analyzed by fitting to simulated data in order to identify radical types, based on g-values and line widths. The results show that at high temperatures, mostly aliphatic radicals $(g=2.0026-2.0028)$ and PAH radicals $(g=2.0027-2.0031)$ were formed.
\end{abstract}

๑) 2016 Elsevier Ltd. All rights reserved.

\section{Introduction}

Understanding pyrolysis of biomass-derived materials is an important step in optimization of biochar production. The application of biomass as a substitute for coal as a reducing agent in metallurgical processes can decrease the direct $\mathrm{CO}_{2}$ emissions [1]. The present technology allows conversion of biomass to biochar, but due to limited knowledge about biochar properties and high costs, the application of biochars is limited [2]. The yield and properties of the biochar, including size, morphology, composition,

\footnotetext{
* Corresponding author.

** Corresponding author.

E-mail addresses: atru@kt.dtu.dk (A. Trubetskaya), mola@food.ku.dk (M.L. Andersen).
}

and reactivity depend strongly on the pyrolysis conditions. Knowledge of the char structure at the molecular level including the presence of free radicals and oxygen heteroatoms is essential for the understanding and prediction of biochar valuable properties in metallurgical applications. The highly reactive biochars are required in a blast furnace, whereas in iron sintering processes, the low reactive biochars are desired [3]. High heat treatment temperature and mineral matter produce free radicals [4,5], which are accumulated at the biochar surface and consequently the reactivity of the sample is increased [6,7]. The mechanical strength of biochars affects significantly the application in metallurgical processes [3]. Higher free radical concentrations favor chemical activity and cross-linking reactions, which enhance the physical and mechanical strength of composites [8,9]. Little is known about the influence of feedstock type on the biochar production and pyrolysis byproducts. 
Electron spin resonance spectroscopy (ESR) has been used in many investigations since the discovery of free radicals in coal by Uebersfeld et al [10]. The electron spin resonance spectroscopy has been used to describe the concentration and chemical structure of free radicals in different coals as reported in the previous studies [10-13]. The majority of investigations on free radical reactions of biomass focused on char generated at slow heating conditions (1-50 $\left.\mathrm{K} \mathrm{min}^{-1}\right)$ and long holding times [14-20].

Bourke et al. [7] investigated high temperature pyrolysis $\left(750-1000^{\circ} \mathrm{C}\right)$ under slow heating of corncob and sucrose, and detected the presence of carbon-centered radicals as a narrow electron spin resonance signal. Moreover, they observed a mixture of narrow and broad ESR signals, arising from two different types of radicals which were a disorganized carbon with unpaired electrons (narrow signal) and an organized carbon with a conductive electron (broad signal). Schurr et al. [18] showed that in a pyrolyzed biomass the g-factor of the ESR signals was related to the remaining oxygen in the char, and when the heat treatment temperature increased, the g-factor decreased and approached the free electron g-factor with a value of 2.0023. As the g-factors were close to the g-factor of a free electron, the EPR signal in the char was mainly derived from unpaired electrons associated with aromatic delocalized $\pi$ system [19]. Similar to coal pyrolysis [12,13,20-23], increasing heat treatment temperature decreased the $\mathrm{O} / \mathrm{C}$ and $\mathrm{H} / \mathrm{C}$ ratios in the biomass, leading to a reduction of the oxygen-centered radicals relative to the original biomass ( $\mathrm{g}=2.0040-2.0060$ ), and formation of the carbon-centered radicals in the char $(\mathrm{g}=2.0025-2.0040)$. Moreover, they observed that more stable carbon-centered radicals than the $\sigma-\mathrm{CH}_{2}$-carbon-centered type were formed. The relevant g-factors for biomass pyrolysis are summarized in Table 1 .

The formation of free radicals is initiated by primary pyrolysis reactions, where the organic compounds are cracked to small unstable radical fragments [23]. These radicals react with more stable low-molecular weight PAH such as naphthalene and may grow into larger high-molecular PAHs structures, containing delocalized unpaired carbon-centered $\pi$-electrons with an additional presence of aliphatic radicals. Due to the homolytic cleavage of $\beta$-aryl-ether bonds of lignin, highly reactive and unstable free radicals are initially obtained that may react through rearrangement, electron abstraction or interactions between radicals, to form stable products as described in the literature [24-26].

During pyrolysis free radicals may detach from the fuel macromolecules, and leave the particle as volatile matter if they have a sufficiently high vapor pressure [27,28]. However, most of them, being reactive, seek stabilization by reacting with reactive species near them [27]. The stabilization of free radicals (cracking, condensing) results in the formation of char and tar from the larger fragments, manifested by the char fluidity decrease [29]. The char may release more volatile matter during reaction stages where radicals are present in high concentrations [27]. More free radicals were proposed to be present in the char matrix. However, many of the radicals generated during pyrolysis were hypothesized to be ESR silent [30] or to disappear from the char matrix after pyrolysis [31-34]. Kihedu et al. [35] reported that free radicals produced during bond breaking in fuels with a high hydrogen level, may prevent repolymerization/cross-linking reactions by the hydrogen donor-acceptor mechanism and therefore decrease the char yield.

The effect of free radicals from the decay stage of pyrolysis (termination stage) at fast heating conditions and at high temperatures (above $1000^{\circ} \mathrm{C}$ ) on the biomass char yield has not been discussed previously. The objective of the present work was to characterize experimentally the remaining free radicals after pyrolysis. The knowledge about remaining free radicals will help to understand the role of free radicals trapped in the solid matrix on the biomass cross-linking/depolymerization. A primary emphasis of the present study was placed on the influence of heating rate and biomass composition effect on the free radical yield and type in the solid char matrix, generated from wood and herbaceous lignocellulosic materials.

\section{Material and methods}

\subsection{Char preparation}

The char samples were obtained in separate pyrolysis experiments performed at a slow heating rate $\left(10 \mathrm{~K} \mathrm{~min}^{-1}\right)$ in the tubular reactor, and at an intermediate heating rate $\left(1000 \mathrm{~K} \mathrm{~s}^{-1}\right)$ in the wire mesh reactor and at a fast heating rate $\left(10^{3}-10^{4} \mathrm{~K} \mathrm{~s}^{-1}\right)$ in the entrained flow reactor.

Wire-mesh reactor. The wire mesh reactor at TU Munich, previously described by Tremel et al. [36], can be operated up to a temperature of $1400^{\circ} \mathrm{C}$, has a maximal heating rate of $3000 \mathrm{~K} \mathrm{~s}^{-1}$, and a maximal pressure of 50 bar. The investigations on the wire mesh reactor were conducted at 1000,1250 and $1400^{\circ} \mathrm{C}$ with a heating rate of $1000 \mathrm{~K} \mathrm{~s}^{-1}$. The holding time on the mesh was $1 \mathrm{~s}$ or $2 \mathrm{~s}$. The schematic top view of the wire mesh reactor is shown in Fig. 1. The temperature distribution on the wire mesh was assumed to be uniform. However, on the mesh side near the electrodes, the temperature was proposed to be lower than in the middle as reported by Hoekstra et al. [37]. In order to ensure high reproducibility of char yield data, the sample was therefore placed centrally. A biomass initial weight of ca. $3 \mathrm{mg}$ was applied for all experiments.

Table 1

g-Factors of radicals found in lignocellulosic materials and their chars.

\begin{tabular}{lll}
\hline g-factor & Description & Ref. \\
\hline Carbon-centered radicals & & \\
$2.0025-2.0026$ & Aliphatic $\pi$ type radicals located on hydrocarbons & Simple $1-5$ rings aromatic hydrocarbons \\
$2.0026-2.0028$ & Graphitic carbon, unsubstituted aliphatic radical & {$[12]$} \\
2.0028 & Complex aromatic hydrocarbons (coronene, benzoperylene) \\
2.0029 & Carbon-centered with an oxygen atom \\
$2.003-2.004$ & Azaaromatics & {$[61,62]$} \\
$2.0030-2.0035$ & Azo compounds \\
$2.0035-2.0042$ & & {$[78]$} \\
Oxygen-centered radicals & $\pi$ type radicals (quinones, 1-3 rings) \\
$2.0038-2.0047$ & Ethers (mono-, di- and trimethoxybenzenes) \\
$2.0035-2.0040$ & Semidioone, semiquinone, ketyl anions \\
$2.0040-2.0060$ & & {$[50]$} \\
Nitrogen-centered radicals & Nitrogen-containing radicals \\
2.0031 & Nitro compounds \\
$2.0045-2.0055$ & Nitroxyls \\
$2.0055-2.0065$ & {$[12]$} \\
\hline
\end{tabular}




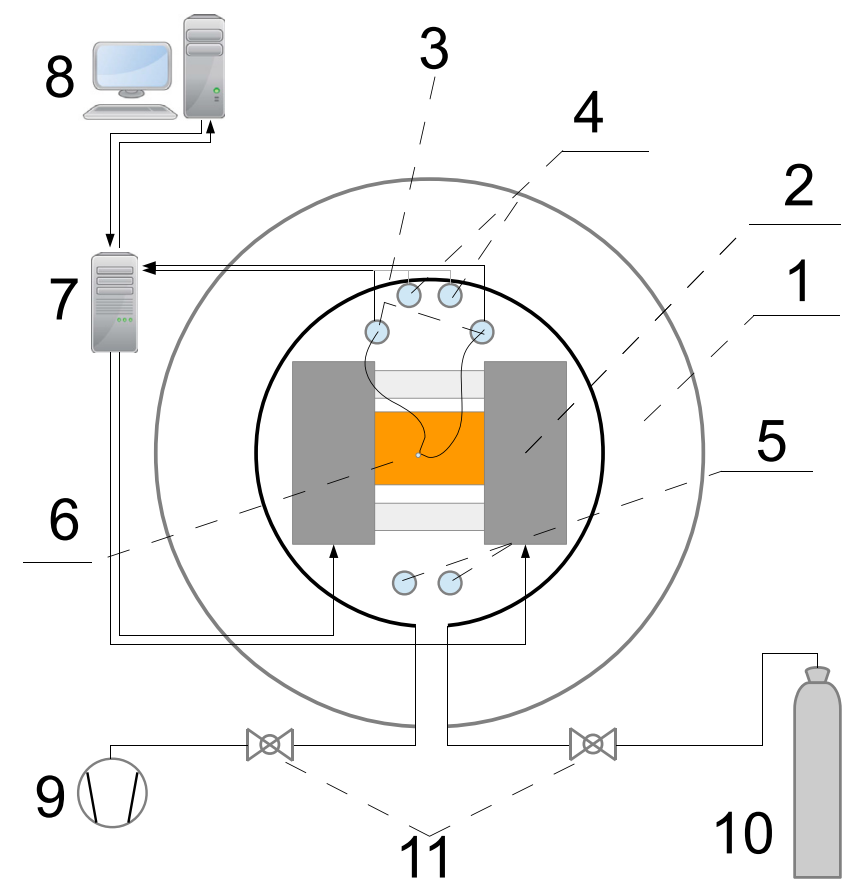

Fig. 1. Schematic top view of the wire mesh reactor at TU Munich: 1 . Reactor steel casing; 2 . Electrodes and holder of the wire mesh with a sample; 3 . Thermocouples Btype; 4. Thermocouples S-type; 5 . Thermocouples K-type; 6 . Wire mesh with a sample; 7. Intensifier; 8. PC with LabVIEW software; 9. Vacuum pump; 10. Gas bottle; 11. Valves [52].

Tubular reactor. A tubular reactor, placed in a furnace (Entech, ETF 3050/15S) was used for the fixed-bed pyrolysis experiments with a heating rate of $<10 \mathrm{~K} \mathrm{~min}^{-1}$ and at a temperature of $1000^{\circ} \mathrm{C}$. The reactor consists of a stainless steel tube with an alumina tube fitted with electrical heating elements and gas supply (Fig. 2). $5 \mathrm{mg}$ of the virgin sample was loaded into the alumina boat placed in the reactor middle. Once the preset temperature was reached, the sample was kept for about $10 \mathrm{~min}$ in the reactor to ensure complete conversion.

Entrained-flow reactor (BabiTER). The entrained flow study was carried out with the Baby High Temperature Entrained Flow Reactor (BabiTER) at TU Munich. The layout of the entrained flow reactor is shown in Fig. $3[38,39]$. The mass flow of the pulverized biomass can be varied from $50 \mathrm{~g} \mathrm{~h}^{-1}$ to $1 \mathrm{~kg} \mathrm{~h}^{-1}$ and is controlled by

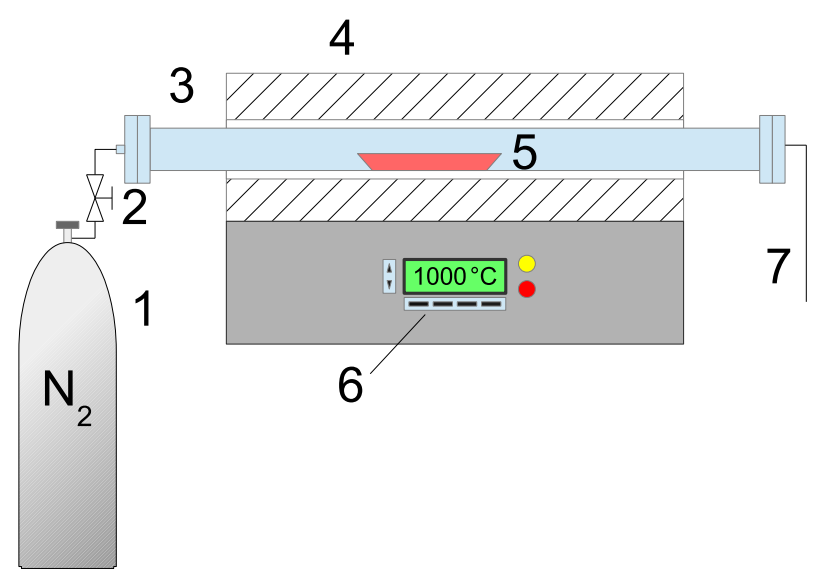

Fig. 2. Schematic view of the tubular reactor at DTU: 1. Gas bottle $\left(\mathrm{N}_{2}\right) ; 2$. Valve; 3 . Ceramic tube; 4. Horizontal tubular reactor; 5 . Quartz boat; 6. Electric heater and temperature controller; 7. Exhaust gas. a software connected to the balances. The pre-heated nitrogen is mixed with the biomass in the entry of the reaction tube. In this work, the experiments were carried out with the entrained flow reactor at temperatures of 1000,1250 and $1500^{\circ} \mathrm{C}$. The BabiTER system is limited to use particles with a characteristic length $<0.5 \mathrm{~mm}$. A biomass feeding rate of $300 \mathrm{~g} \mathrm{~h}^{-1}$ was selected for the rice husk. At 1000 and $1250^{\circ} \mathrm{C}$, the wheat straw and leached wheat straw was fed with $200 \mathrm{~g} \mathrm{~h}^{-1}$, and at $1500^{\circ} \mathrm{C}$ with $100 \mathrm{~g} \mathrm{~h}^{-1}$ to ensure continuous biomass feeding. The sampling probe was kept at a constant height, enabling a residence time of about $1 \mathrm{~s}$ during all experiments.

Char yield determination in the wire mesh and entrained flow reactors. The average char yield was determined from at least five pyrolysis experiments in the wire mesh reactor for each condition. The char yield $\left(\mathrm{Y}_{S}\right)$ in the wire mesh reactor was calculated according to equation (1):

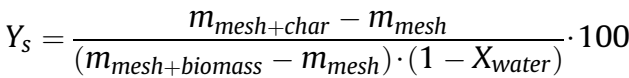

where $\mathrm{X}_{\text {water }}$ is the mass fraction of moisture in the original biomass. The char yield of the Si-rich wheat straw and rice husk in the entrained flow reactor including ash was quantified by using $\mathrm{Si}$ as a non-volatile tracer element, as proposed by Damø et al. [40], according to equation (2):

$Y_{S}=100 \cdot \frac{c_{\text {Si,fuel }}}{c_{\text {Si,char }}}$

$\mathrm{C}_{\text {Sifuel }}$ is Si mass fraction of the dry fuel, $\mathrm{c}_{\text {Si,char }}$ is Si mass fraction of the dry char. The method with application of silicon as an ash tracer is based on the assumption that all Si is retained in the char.

\subsection{Materials and methods}

\subsubsection{Biomass composition}

Prior to the pyrolysis experiments, pinewood, beechwood, wheat straw and rice husk were comminuted on a hammer mill and sieved to the particle size fractions $0.05-0.2 \mathrm{~mm}$ for the wire mesh and tubular reactor experiments and to $0.09-0.18 \mathrm{~mm}$ for the entrained flow reactor study. The raw Scots pinewood (Pinus sylvestris L.) originates from Jylland (Denmark), whereas beechwood (Fagus sylvatica) was harvested in Hannover (Germany). The raw rice husk (Oryza sativa L.) and wheat straw (Triticum aestivum L.) originate from North Vietnam (Sapa plantage) and Denmark (Aabenraa plantage). For the individual biomass compounds organosolv lignin (Alcell) from loblolly pinewood (Pinus taeda) (BOC Sciences, US) and lignin from wheat straw (BOC Sciences, US), xylan from beechwood (purity 97.3\%, Sigma-Aldrich, St. Louis, US) and cellulose (Avicel PH-101, Sigma-Aldrich, US) were used. Xylan from beechwood (Fagus sylvatica) originates from North America, and consists of 1,4 -linked $\beta$-xylopyranosyl units substituted by $4-O$ methyl- $\alpha$-D-glucopyranosyl uronic acid units [41]. The xylosyl-touronic acid ratio is 8:1. Organosolv lignin from wheat straw originates from wheat residues in Eastern Oregon (US), whereas organosolv lignin from softwood was harvested in Arkansas (US).

The wheat straw was leached in deionized water (room temperature) by continuous stirring for $12 \mathrm{~h}$, followed by drying at $30^{\circ} \mathrm{C}$ in an oven desiccator without any ventilation. The mineral content after biomass leaching was determined by ash analysis. Due to the wheat straw leaching, the metal content was reduced to $\approx 60 \%$ of the original value and the $\mathrm{Cl}, \mathrm{S}, \mathrm{K}, \mathrm{Na}$ and $\mathrm{P}$ contents were strongly reduced.

The proximate and ultimate analyses of fuels are shown in Table 2. The compositional analysis of lignocellulosic materials 


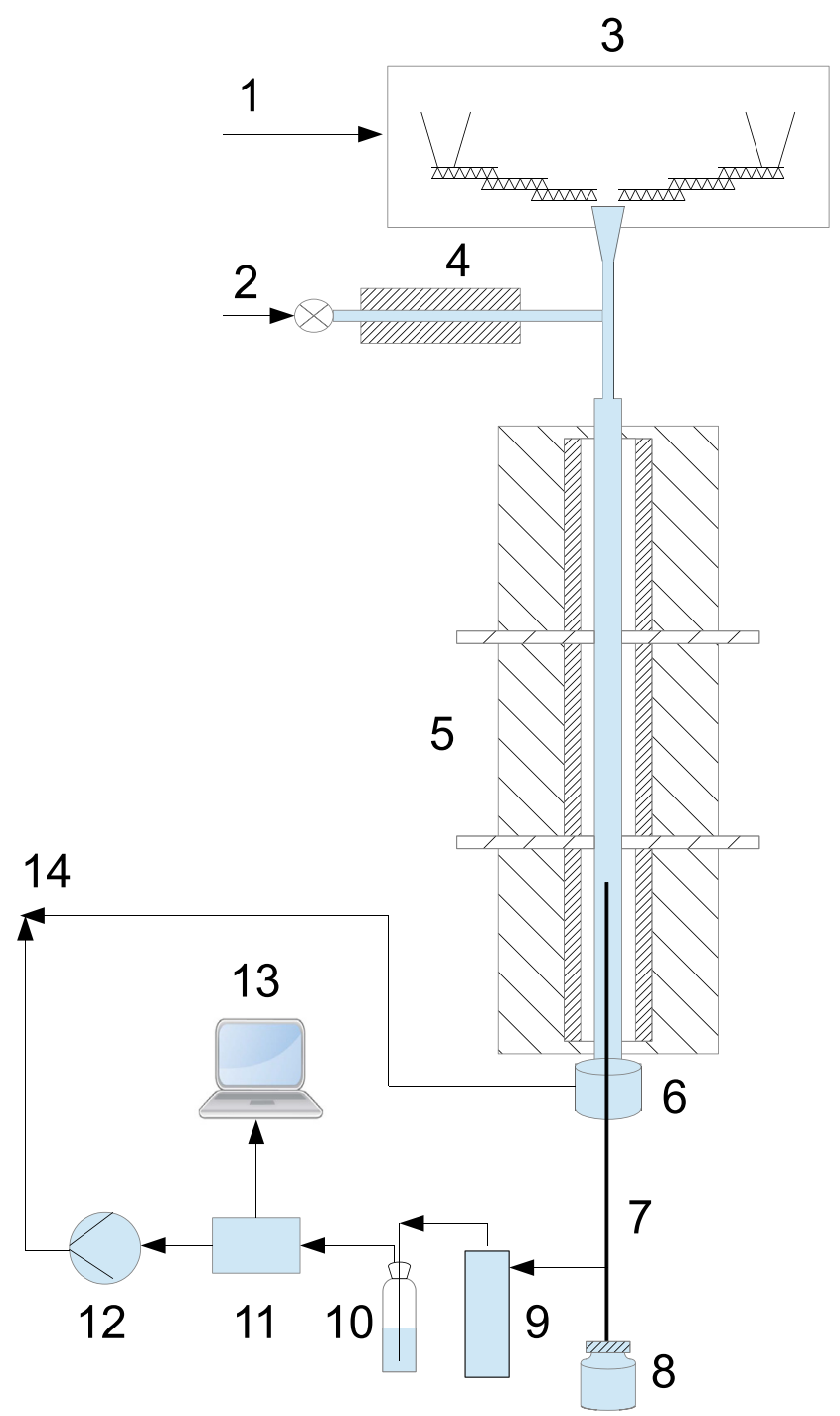

Fig. 3. Schematic view of the entrained flow reactor (BabiTER) at TU Munich [38,39]: 1 . Feeding gas $\left(\mathrm{N}_{2}\right) ; 2$. Main gas $\left(\mathrm{N}_{2}\right)$; 3. Fuel feeding system; 4. Pre-heater; 5. Tube furnace; 6 . Water quench; 7. Collection probe; 8 . Solid residue char bin; 9. Metal filter; 10. Impinger bottle; 11. Gas analyzer; 12. Pump (Venturi); 13. Gas analysis/measurement controller; 14. Exhaust gas [84].

(cellulose, hemicellulose, acid-soluble lignin, acid-insoluble lignin, protein and extractives) was conducted according to NREL technical reports [42-44] and Thammasouk et al. [45], and shown in Table 3. The water-ethanol extraction was performed on wheat straw, alfalfa straw and rice husk which contain a high level of hydrophilic and lipophilic extractable compounds [45]. The extraction comprised of a water extraction after which the remaining solid was extracted in 95\% ethanol, as described by Thammasouk et al. [45]. In addition, the original sample was also extracted using 95\% ethanol. These operations allowed for the determination of the total amount of water-soluble extractives, ethanol-soluble extractives, and water-insoluble but ethanol-soluble extractives, as well as the total extractives removed under a sequential extraction using water and then ethanol.

\subsubsection{Methods}

Elemental analysis. The elemental analysis was performed in quadruplicates on two instruments of the same model (Eurovector, model EA3000) to determine CHN and oxygen contents of chars prepared in the tubular, wire mesh, and BabiTER reactors. Acetanilide was used as a reference standard. The ash content of the chars was determined using a muffle oven.

Ash compositional analysis. The ash content of $1 \mathrm{~g}$ raw biomass and char samples was determined in triplicates by oxidation at $550^{\circ} \mathrm{C}$ for $7 \mathrm{~h}$ in the muffle oven [46]. The ash compositional analysis was performed by an X-ray fluorescence instrument (Shimadzu, model EDX 800-HS) at TU Munich. The ash (about $200 \mathrm{mg}$ ) which was generated at $550^{\circ} \mathrm{C}$ was initially mixed and then pressed with a special wax (mixture ratio 1:5). The $\mathrm{Cl}$ and $\mathrm{S}$ content in the ash was analyzed by ion chromatography (IC) at TU Wien. The ash sample was dissolved in ultrapure water at $120^{\circ} \mathrm{C}$ for $1 \mathrm{~h}$, and then the solution was filtered and analyzed by IC.

${ }^{13} \mathrm{C}$ solid state NMR spectroscopy. Solid-state NMR analysis was carried out on a Bruker Avance 400 NMR spectrometer (9.4 T) operating at Larmor frequencies of $400.13,100.58$ and $79.48 \mathrm{MHz}$ for ${ }^{1} \mathrm{H}$ and ${ }^{13} \mathrm{C}$ respectively. All experiments were conducted using a double resonance probe equipped with $4 \mathrm{~mm}$ (o.d.) rotors. Samples were analyzed at room temperature by single-pulse (SP) magic angle spinning (MAS) as well as cross polarization (CP) MAS [47] utilizing high-power ${ }^{1} \mathrm{H}$ two-pulse phase-modulated decoupling (TPPM) [48] during acquisition and employing a spin-rate of $9 \mathrm{kHz}$. The ${ }^{13} \mathrm{C} C \mathrm{CP} / \mathrm{MAS}$ spectra were recorded using a recycle delay of $8 \mathrm{~s}$, a contact time of $1 \mathrm{~m}$, an acquisition time of $45.9 \mathrm{~m}$ and 4096 scans, whereas the ${ }^{13} \mathrm{C}$ SP/MAS spectra were recorded using a recycle delay of $128 \mathrm{~s}$, an acquisition time of $45.9 \mathrm{~m}$ and 1080 scans. All ${ }^{13} \mathrm{C}$ NMR spectra were referenced to the carbonyl resonance of an external sample of $\alpha$-glycine at $176.5 \mathrm{ppm}$.

Electron spin resonance spectroscopy. Electron spin resonance (ESR) spectra were recorded on a Jeol JES-FR30 ESR spectrometer (JEOL Ltd., Tokyo, Japan). Samples were placed in a closed-bottom quartz capillary tube with a wall thickness of $0.75 \mathrm{~mm}$ and an outer diameter of $5 \mathrm{~mm}$. The measurements were carried out at room temperature with a microwave power of $4 \mathrm{~mW}$, and a modulation width of $0.1 \mathrm{mT}$, sweep width of $50 \mathrm{G}$, sweep time of $0.5 \mathrm{~min}$, time constant of $0.3 \mathrm{~s}$. The intensity of all signals was recorded relative to the intensity of a Mn (II)-marker (JEOL Ltd., Tokyo, Japan) attached to the cavity of the spectrometer. Since the area under the ESR adsorption curve is directly proportional to the number of paramagnetic centers contributing to the resonance, the spin concentration (spins $\mathrm{g}^{-1}$ ) of a sample, $\mathrm{N}_{\text {s.spin }}$, was calculated by comparing the double integrated areas of the sample signals, $\mathrm{A}_{\text {sample }}$, and the $\mathrm{Mn}$ (II) internal marker signals as shown in equation (3) [49]:

$N_{\text {s.spin }}=\frac{N_{\text {marker }} \cdot A_{\text {sample }}}{A_{\text {marker }}}$

A solid sample of $\mathrm{CuSO}_{4} \cdot 5 \mathrm{H}_{2} \mathrm{O}$ of known weight was used as a standard for calculating the number of spins in the Mn (II)-marker signals as shown in equation (4) [50]:

$N_{\text {marker }}=\frac{n_{\mathrm{CuSO}_{4} \cdot 5 \mathrm{H}_{2} \mathrm{O}} \cdot N_{\mathrm{A}} \cdot A_{\text {marker }}}{A_{\mathrm{CuSO}_{4}} \cdot 5 \mathrm{H}_{2} \mathrm{O}}$

The calculation of a spin sample concentration $\left(\mathrm{c}_{\text {s.spin }}\right)$ is based on the ratio of a number of spins and a sample weight $\left(\mathrm{m}_{s}\right)$ using equation (5) [50]:

$c_{\text {s.spin }}=\frac{N_{\text {s.spins }}}{m_{S}}$

The ESR g-factor is determined in equation (6) [50]:

$g=\frac{g_{1} \cdot H}{H+H_{1}}$ 
Table 2

Proximate and ultimate analysis of fuels and ash analysis.

\begin{tabular}{|c|c|c|c|c|c|c|c|c|}
\hline Fuel & Pinewood & Beechwood & Wheat straw & $\begin{array}{l}\text { Leached } \\
\text { wheat straw }\end{array}$ & $\begin{array}{l}\text { Rice } \\
\text { husk }\end{array}$ & $\begin{array}{l}\text { Lignin wheat } \\
\text { straw }\end{array}$ & $\begin{array}{l}\text { Lignin } \\
\text { softwood }\end{array}$ & $\begin{array}{l}\text { Xylan from } \\
\text { beechwood }\end{array}$ \\
\hline \multicolumn{9}{|l|}{ Proximate analysis } \\
\hline Moisture, (\% as received) & 5.1 & 4.5 & 5.5 & 4.3 & 4.5 & 4.4 & 6.1 & 3.3 \\
\hline Ash $\left(550^{\circ} \mathrm{C}\right),(\%$ dry basis $)$ & 0.3 & 1.4 & 4.1 & 2 & 21.7 & 3.6 & 1.3 & 2 \\
\hline Volatiles, (\% dry basis) & 86.6 & 79.4 & 77.5 & 84.2 & 64.3 & 66.3 & 67.3 & 81.6 \\
\hline $\mathrm{HHV},\left(\mathrm{MJ} \mathrm{kg}^{-1}\right)$ & 21.6 & 20.2 & 18.8 & 18.7 & 15.5 & 26.7 & 26.4 & 14 \\
\hline $\mathrm{LHV},\left(\mathrm{MJ} \mathrm{kg}^{-1}\right)$ & 20.2 & 19 & 17.5 & 17.4 & 14.5 & 25.5 & 25.2 & 14 \\
\hline \multicolumn{9}{|c|}{ Ultimate analysis, (\% dry basis) } \\
\hline $\mathrm{C}$ & 50.5 & 46.7 & 42.4 & 45.7 & 35.5 & 61.8 & 64.6 & 39.7 \\
\hline $\mathrm{H}$ & 6.8 & 6.3 & 6.3 & 6.6 & 5.5 & 3.8 & 5.3 & 6.1 \\
\hline $\mathrm{O}$ & 42.3 & 45.3 & 46.2 & 45.4 & 37.2 & 29.4 & 28 & 51.9 \\
\hline $\mathrm{N}$ & 0.1 & 0.3 & 1 & 0.3 & 0.1 & 1.4 & 0.8 & 0.3 \\
\hline S & $<0.01$ & 0.02 & 0.1 & 0.02 & 0.03 & 0.8 & 0.1 & 0.02 \\
\hline $\mathrm{Cl}$ & 0.01 & 0.02 & 0.1 & 0.01 & 0.05 & 0.03 & 0.5 & 0.01 \\
\hline \multicolumn{9}{|c|}{ Ash compositional analysis, ( $\mathrm{mg} \mathrm{kg}^{-1}$ dry basis) } \\
\hline $\mathrm{Al}$ & 10 & 10 & 150 & 100 & 70 & 300 & 100 & 10 \\
\hline $\mathrm{Ca}$ & 600 & 2000 & 2500 & 1300 & 750 & 200 & 250 & 5700 \\
\hline $\mathrm{Fe}$ & 20 & 10 & 200 & 350 & 80 & 1400 & 600 & 150 \\
\hline K & 200 & 3600 & 11000 & 1300 & 2500 & 270 & 80 & 180 \\
\hline $\mathrm{Mg}$ & 100 & 600 & 750 & 350 & 400 & 40 & $<30$ & 80 \\
\hline $\mathrm{Na}$ & 30 & 100 & 150 & 50 & 70 & 6800 & 4100 & 19200 \\
\hline $\mathrm{P}$ & 6 & 150 & 550 & 80 & 600 & 30 & 30 & 150 \\
\hline $\mathrm{Si}$ & 50 & 200 & 8500 & 6200 & 98500 & 4000 & 900 & 3 \\
\hline $\mathrm{Ti}$ & 2 & $<8$ & 10 & 10 & 5 & 100 & 50 & 100 \\
\hline
\end{tabular}

In equation (6), $\mathrm{g}_{1}$-factor of a digital marker (1.981), $\mathrm{H}_{1}$ and $\mathrm{H}$ are positions of the digital marker $(\mathrm{H}=335.7 \mathrm{mT})$ and signal center $(\mathrm{H}=337.1 \mathrm{mT})$.

Fitting of experimental ESR-spectra to simulated data was done using WinSim software, as described by Duling et al. [51]. The WinSim software is based on the LMB and simplex optimization methods to fit an experimental ESR spectrum to a combination of simulated free radical ESR spectra. Each spectra was assumed to be isotropic, spin $=1 / 2$ without contributions from hyperfine splittings. The simulation of spectra gave the relative amounts of radical derivatives as well as optimized values of line widths and g-factors. Optimizations gave best fits to the experimental ESR spectra with a root mean square $(\mathrm{RMS})>0.85$.

The ESR analysis of biomass char was conducted the next day after char generation, and compared with the results seven month later. The radical concentration showed negligible differences $(<5 \%)$ over a period of seven month, and therefore being independent on the storage time.

\section{Results}

\subsection{Char characterization}

\subsubsection{Char yield}

The char yields generated at $1000^{\circ} \mathrm{C}$ in the wire mesh reactor and at $1000-1500^{\circ} \mathrm{C}$ in the entrained flow reactor were determined for all lignocellulosic materials (Fig. 4(a)). The char yields on dry ash free basis (daf) of rice husk, leached wheat straw and pinewood in the wire mesh reactor were equally similar and low (ca. 4\% daf). The alkali lean rice husk, leached wheat straw and pinewood show a significant variation in biomass major compounds. This indicates that any differences in biomass composition (cellulose, hemicellulose and lignin) between straw and wood only result in small char yield differences. The char yields of beechwood (rich in $\mathrm{Ca}, \mathrm{K}$ ) and wheat straw (rich in $\mathrm{Ca}, \mathrm{K}, \mathrm{Si}$ ) were $4-10 \%$ points higher than char yields from pyrolysis of other lignocellulosic materials which was associated with the catalytic effect of alkali metals that affect polymerization/cross-linking [52].

The char yield from pyrolysis of wheat straw at $1000^{\circ} \mathrm{C}$ in the entrained flow reactor was $7 \%$ lower than the char yield in the wire mesh reactor, due to the differences in heating rate and residence time (Fig. 4(b)). The pyrolysis in the wire mesh reactor was carried out with a lower heating rate $\left(1000 \mathrm{~K} \mathrm{~s}^{-1}\right)$ than in the entrained flow reactor $\left(10^{4} \mathrm{~K} \mathrm{~s}^{-1}\right)$. The char yield of wheat straw decreased with increasing temperature, indicating a dependency of the char yield on the heat treatment temperature. An opposite tendency was observed during the rice husk pyrolysis, where the char yield decreased only slightly from 5 to $3.5 \%$ by weight in a temperature range of $1000-1500^{\circ} \mathrm{C}$. The heat treatment temperatures and silica contents did not seem to affect the char yield of rice husk, based on the small differences in char yields obtained at 1000, 1250 and $1500^{\circ} \mathrm{C}$

The wheat straw and rice husk chars were collected from the fast pyrolysis in the entrained flow reactor, and were analyzed by

Table 3

Biomass feedstock composition, calculated in percentage based on dry weight (\% dry basis).

\begin{tabular}{|c|c|c|c|c|c|c|c|}
\hline \multirow[t]{2}{*}{ Biomass } & \multirow[t]{2}{*}{ Cellulose } & \multirow[t]{2}{*}{ Hemi-cellulose } & \multicolumn{2}{|l|}{ Lignin } & \multirow[t]{2}{*}{ Totallignin } & \multirow[t]{2}{*}{ Extractives } & \multirow[t]{2}{*}{ Protein } \\
\hline & & & Acid insoluble & Acid soluble & & & \\
\hline Pinewood & 38.3 & 17.8 & 29.6 & 1.8 & 31.4 & $8.8^{\mathrm{a}}$ & 0.6 \\
\hline Beechwood & 35 & 19.2 & 32 & 1.5 & 33.5 & $7.5^{\mathrm{a}}$ & 1.9 \\
\hline Wheat straw & 35.9 & 18 & 19.2 & 6.5 & 25.7 & $10.1^{\mathrm{b}}$ & 6.3 \\
\hline Leached wheat straw & 32.1 & 23.5 & 13.8 & 2 & 15.8 & $13.3^{\mathrm{b}}$ & 1.3 \\
\hline Rice husk & 36.7 & 17.7 & 21.6 & 1.2 & 22.8 & $1^{\mathrm{b}}$ & - \\
\hline
\end{tabular}

a Acetone extraction.

b Ethanol-water extraction at room temperature. 
X-ray fluorescence (XRF), Inductively Coupled Plasma Optical Emission Spectroscopy (ICP-OES) and Ion Chromatography (IC). The results of ash compositional analysis of original wheat straw, rice husk and their chars are shown in Fig. 5. The analysis of rice husk chars generated at temperatures of $1000-1500^{\circ} \mathrm{C}$ indicated high concentrations of silicon oxides along with smaller amounts of potassium, aluminium, iron, sodium and magnesium. The wheat straw char at all applied heat treatment temperatures contained potassium and calcium along with a high concentration of silicon, leading to the formation of silicates [53]. About $70 \%$ of potassium has been released during wheat straw pyrolysis in a temperature range of $1000-1500^{\circ} \mathrm{C}$, and potassium at $1500^{\circ} \mathrm{C}$ is bound to silicates (Fig. 5). The ash compositional analysis of wood and herbaceous biomass chars obtained in the wire mesh and tubular reactors was not performed due to the limited amount of the biomass chars.

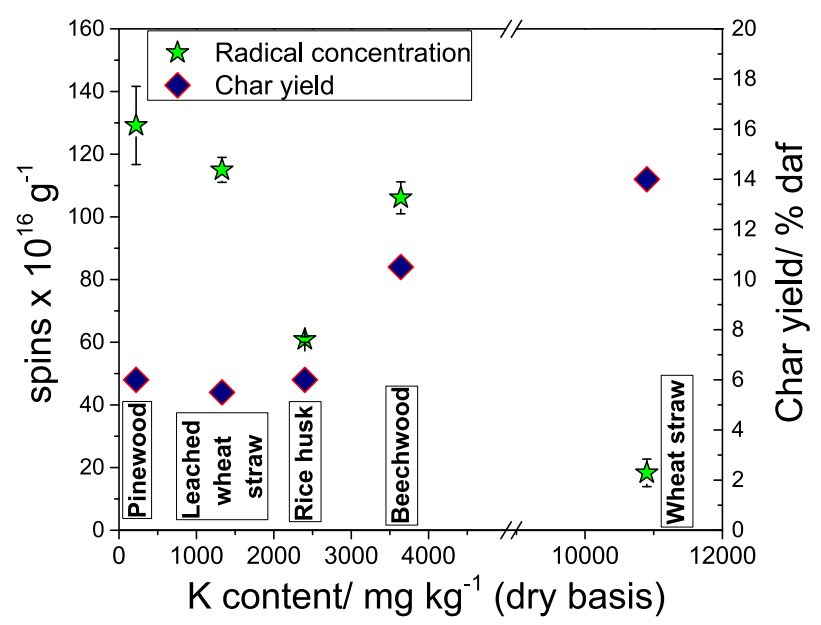

(a): Char yield and radical concentrations in the WMR

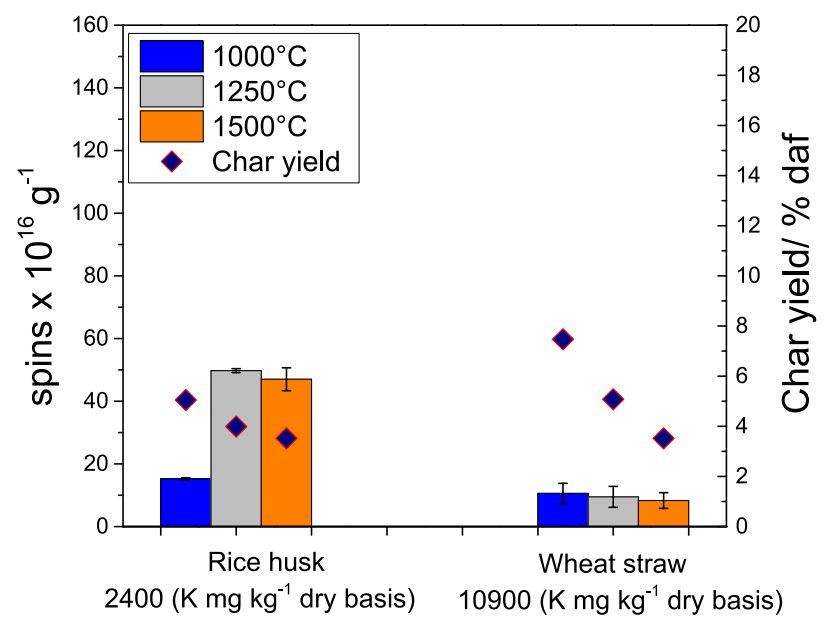

(b): Char yield and radical spin concentration in the EFR

Fig. 4. Char yields (blue-red diamonds) and ESR concentration (spins $x 10^{16} \mathrm{~g}^{-1}$ ): 4(a) pinewood, beechwood, rice husk, leached wheat straw and wheat straw chars prepared in the wire mesh reactor (heat treatment temperature: $1000^{\circ} \mathrm{C}$, heating rate: $1000 \mathrm{~K} \mathrm{~s}^{-1}$, holding time: $1 \mathrm{~s}$ ) and shown as green stars; 4(b) wheat straw and rice husk chars prepared in the entrained flow reactor (heat treatment temperatures: 1000 , 1250 and $1500^{\circ} \mathrm{C}$ ) versus potassium content in the original lignocellulosic materials. (For interpretation of the references to colour in this figure legend, the reader is referred to the web version of this article.)

\subsubsection{Elemental analysis}

Fig. 6 shows a Van Krevelen plot of original lignocellulosic materials and their chars, generated in the wire mesh, tubular and entrained flow reactors to study the effect of heating rate and heat treatment temperature on the char composition. The results in Fig. 6(a) indicate that the oxygen content in rice husk char is higher than in beechwood and wheat straw chars. Fig. 6(b) shows that temperatures above $1000^{\circ} \mathrm{C}$ led to an increase in the carbon content of the rice husk and wheat straw chars due to the preferential release of hydrogen, oxygen and nitrogen.

\subsection{3. ${ }^{13} \mathrm{C}$ solid state NMR spectroscopy}

The effect of temperature on the organic matter transformation of char prepared in the wire mesh reactor and tubular reactor, was investigated using ${ }^{13} \mathrm{C} \mathrm{CP} / \mathrm{MAS}$ and ${ }^{13} \mathrm{C}$ SP/MAS NMR. The NMR spectra are displayed in Fig. 7 and the associated spectral assignments are shown in Table 4.

The most intense resonance in the ${ }^{13} \mathrm{C}$ MAS NMR spectra of chars is a broad resonance centered at $125 \mathrm{ppm}$ indicating the presence of disordered aromatic residues, whereas resonances originating from cellulose (amorphous and crystalline), hemicellulose and lignin were observed in the spectra of the original lignocellulosic materials. It was noted that the $\mathrm{CP} / \mathrm{MAS}$ and SP/MAS spectra of original lignocellulosic materials were almost identical, whereas differences between these two spectra were observed for the chars. During the char formation charged species are formed and some of these are paramagnetic. As reported previously [54], the presence of paramagnetics will increase relaxation rates and line widths. In close proximity of the paramagnetic sites this may even broaden the resonances beyond the limit of detection. For the wheat straw and rice husk heated at $10 \mathrm{~K} \mathrm{~min}^{-1}$ no resonances were observed in the $\mathrm{CP} / \mathrm{MAS}$ spectra. The remains of polysaccharides and lignin were detected in the $\mathrm{CP} / \mathrm{MAS}$ spectra of beechwood and rice husk samples heated at $1000 \mathrm{~K} \mathrm{~s}^{-1}$. This indicates the increased aromatization of the lignocellulosic material and formation of more graphene-like structures compared to chars generated in the wire mesh reactor [55]. Since these compounds were not observed in the corresponding SP/MAS spectra, this means that it is only a small fraction of the immobile part of the sample that contained polysaccharides and lignin.

No resonances were observed in the $\mathrm{CP} / \mathrm{MAS}$ spectra of wheat straw and rice husk chars generated at slow heating rate $\left(10 \mathrm{~K} \mathrm{~min}^{-1}\right.$ ) whereas a resonance in the spectrum of beechwood

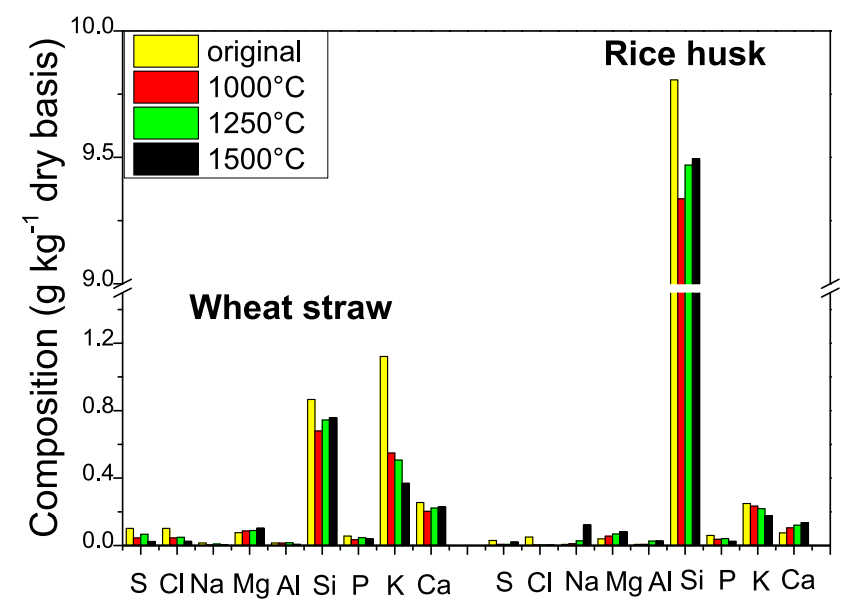

Fig. 5. Ash compositional analysis of rice husk and wheat straw pyrolyzed in the BabiTER reactor at 1000,1250 and $1500^{\circ} \mathrm{C}$. The ash composition of both lignocellulosic materials and their chars is shown in $\mathrm{g} \mathrm{kg}^{-1}$ on dry basis [84]. 


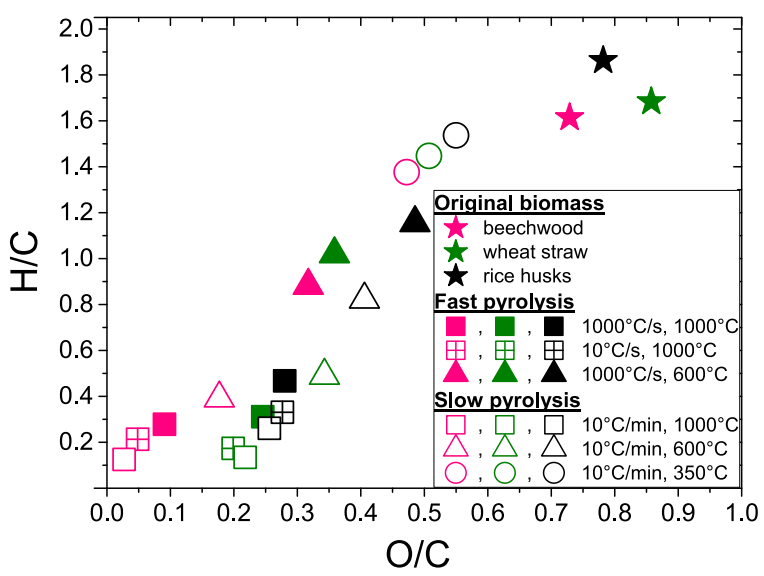

(a): Van Krevelen plot of chars prepared in the wire mesh and tubular reactors

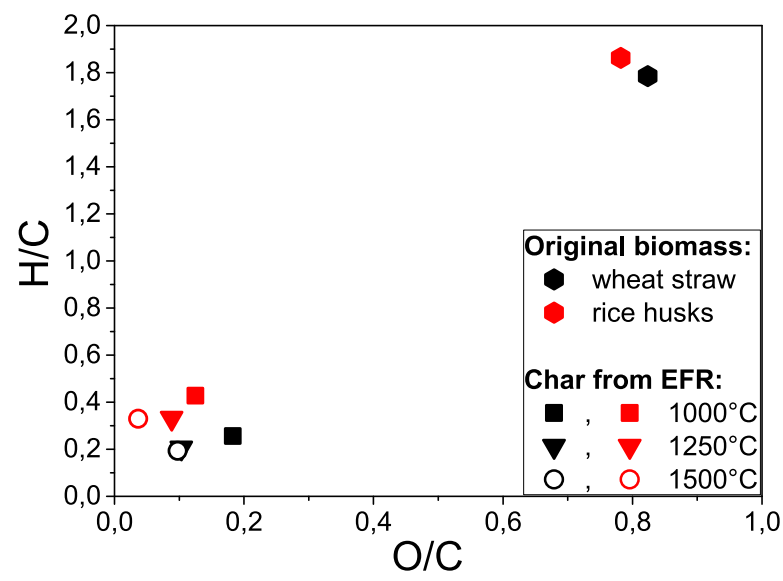

(b): Van Krevelen plot of chars prepared in the entrained flow reactor

Fig. 6. Van Krevelen plot of original biomass and their chars prepared 6(a) in the tubular reactor (heat treatment temperature: 350,600 and $1000^{\circ} \mathrm{C}$; heating rate: $10 \mathrm{~K} \mathrm{~min}^{-1}$; holding time: $10 \mathrm{~min}$ ) and in the wire mesh reactor (heat treatment temperature: 600 and $1000^{\circ} \mathrm{C}$; heating rate: $10 \mathrm{~K} \mathrm{~s}^{-1}$ and $1000 \mathrm{~K} \mathrm{~s}^{-1}$; holding time: $1 \mathrm{~s}) ; 6$ (b) in the entrained flow reactor (heat treatment temperatures: 1000, 1250 and $\left.1500^{\circ} \mathrm{C}\right)$.

was present. Comparison with the $\mathrm{H} / \mathrm{C}$ - and O/C-ratios in Fig. 6 shows that $\mathrm{H} / \mathrm{C}$ ratios of beechwood are similar to the values for wheat straw, whereas the $\mathrm{O} / \mathrm{C}$ ratio for slowly heated beechwood is a factor of 8-10 lower than wheat straw and rice husk. The lower oxygen content makes the beechwood less sensitive to effects of charged species such as paramagnetics. According to Fig. 8(a), the number of paramagnetic spins in beechwood is higher that in wheat straw and rice husk. Therefore, it is not the amount of paramagnetics that is the main reason for the lack of CP efficiency for wheat straw and rice husk. It is rather a high oxygen abundance that leads to a higher sensitivity towards paramagnetics in the sample.

\subsection{Electron spin resonance spectroscopy}

\subsubsection{Spin radical concentration}

Spin concentrations of free radicals trapped in the chars were measured using electron spin resonance spectroscopy (ESR). The effects of heating rate $\left(10 \mathrm{~K} \mathrm{~min}^{-1}\right.$ or $\left.1000 \mathrm{~K} \mathrm{~s}^{-1}\right)$, holding time (1 or
$2 \mathrm{~s}$ ) and biomass origin (wood or herbaceous biomass) on the spin radical concentration at $1000^{\circ} \mathrm{C}$ were investigated.

Fig. 8(a) shows that the radical concentrations in wood chars were significantly higher than in herbaceous chars at $1000^{\circ} \mathrm{C}$. The radical concentration in biomass chars, pyrolyzed in the wire mesh reactor was up to $60 \%$ higher than in chars from the tubular reactor. The ESR signal intensities decreased when holding time was increased from 1 to $2 \mathrm{~s}$ in the wire mesh reactor (Fig. 8(b)). The ESR signal intensities in chars from beechwood hemicellulose and lignin are compared in Fig. 8(c). The Avicel cellulose char, prepared at $1000^{\circ} \mathrm{C}$ in the wire mesh reactor, did not show ESR signals of any free radicals (data not shown). Chars produced by pyrolysis of hemicelluloses had lower concentration of radicals than chars from pyrolysis of lignin due to the aromatic structure of lignin. This results suggest a significantly influence of lignin on the radical concentration of chars at the decay stage [8]. Radicals generated from the primary pyrolysis reactions can be trapped in the polyaromatic matrix of lignin [56], and stabilized by the delocalized unpaired electrons [57,58]. The major products from cellulose pyrolysis (levoglucosan and other light oxygenates) do not have unpaired electrons [59], and therefore, the radical concentrations in the char from the decay stage are low. The char prepared from softwood lignin at $1000^{\circ} \mathrm{C}$ with $1 \mathrm{~s}$ holding time showed a higher concentration of radicals than the wheat straw lignin char. However, smaller differences in radical concentrations between leached wheat straw and beechwood chars indicate a minor effect of the lignin composition than the alkali influence on remaining radical concentrations.

In the entrained flow reactor, free radicals were not observed in the wood and leached wheat straw chars at $1000-1500^{\circ} \mathrm{C}$. The concentrations of radicals in the wheat straw char changed only slightly with increasing temperature in the entrained flow reactor. In contrast, the concentrations of remaining radicals in the rice husk char increased above $1000^{\circ} \mathrm{C}$ (Fig. 8(d)).

\subsection{2. g-Factors and radical types}

The experimental ESR-spectra were analyzed by fitting to simulated spectra in order to identify radical species. A model based on a mixture of two radical types which were assigned to carbon-centered and oxygen-centered polyaromatic radicals was found to adequately fit the experimental ESR spectra. This allowed determination of relative amounts of the radicals and their g-values and line widths. The fitting of simulated ESR-spectra to the experimental spectra of the original beechwood and rice husk chars prepared in the wire mesh reactor are shown in Fig. 9. The ESR signals were symmetric without hyperfine splittings for the original biomass and as well as its chars formed under both slow and fast heating (Fig. 10(a)). The ESR lines were a mixture of Lorentzian and Gaussian fitting, yet with the dominating Lorentzian shape.

The fitted ESR spectra of the original lignocellulosic materials had line widths (LW) in the range 1.7-7.1 G and g-factors in the range 2.0031-2.0052, while the spectra of the chars gave $\mathrm{LW}=2.5-7.1 \mathrm{G}$ and $\mathrm{g}=2.0026-2.0046$ (Tables 5 and 6). Radicals with g-factors outside the range 2.002-2.006 were not observed in the present study. Sulfur radicals were probably not present in the char matrix due to the higher g-values of sulfur-containing radicals ( $\mathrm{g}=2.0080-2.0081)$. Nitrogen-containing radicals that have gvalues similar to the oxygen-containing radicals ( $g=2.0031$ ), but usually have broad line widths (5.7-8.2) G [60], cannot be excluded based on values (Tables 5 and 6). However, the hyperfine coupling to ${ }^{14} \mathrm{~N}$ was not detected. Thus, the presence of nitrogen-containing radicals is less likely.

The original lignocellulosic materials and compounds gave ESR spectra with radicals with higher g-values than their derived chars, indicating higher levels of oxygen-containing radicals (Tables 5 and 


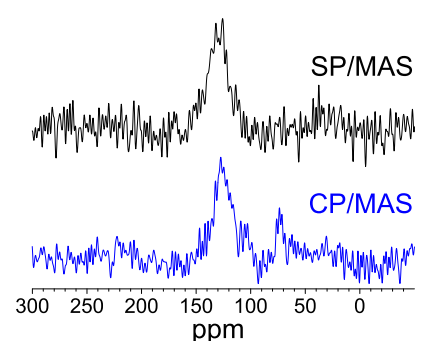

(a): Beechwood, $1000 \mathrm{~K} \mathrm{~s}^{-1}$

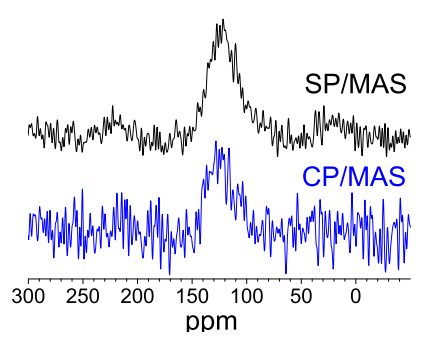

(d): Beechwood, $10 \mathrm{~K} \mathrm{~min}^{-1}$

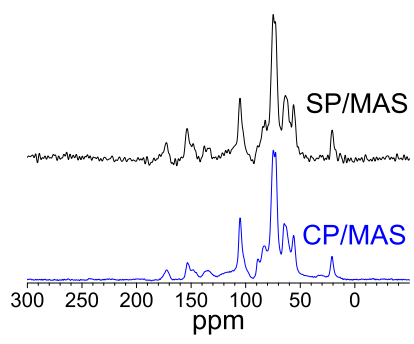

(g): Beechwood, raw

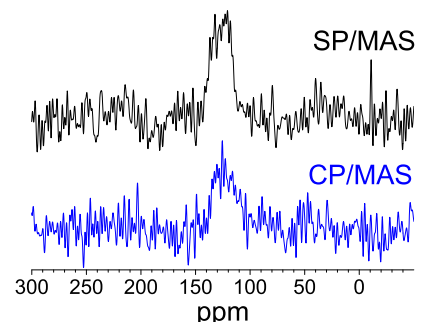

(b): Straw, $1000 \mathrm{~K} \mathrm{~s}^{-1}$

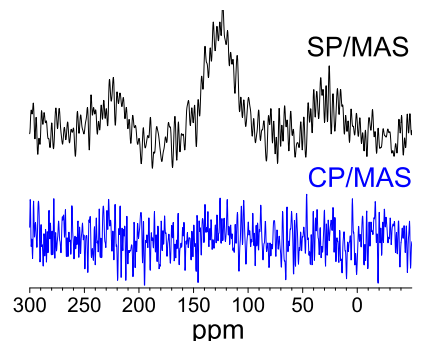

(e): Straw, $10 \mathrm{~K} \mathrm{~min}^{-1}$

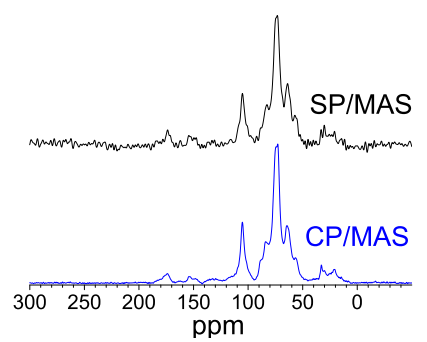

(h): Straw, raw

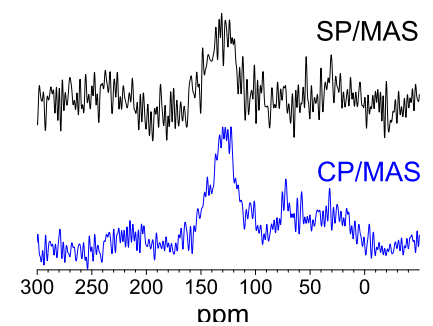

(c): Rice husk, $1000 \mathrm{~K} \mathrm{~s}^{-1}$

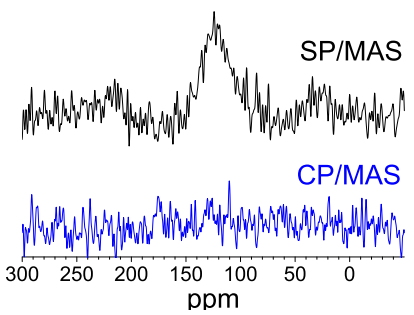

(f): Rice husk, $10 \mathrm{~K} \min ^{-1}$

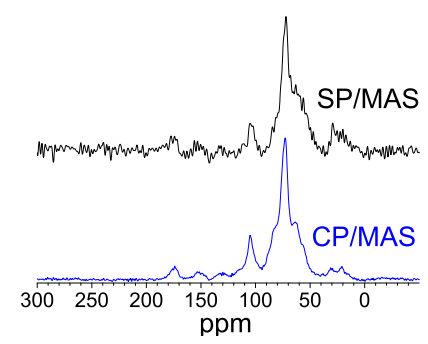

(i): Rice husk, raw

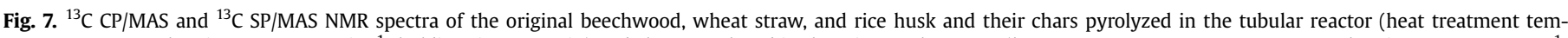

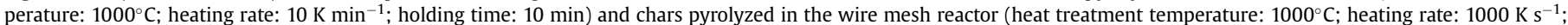
holding time: $1 \mathrm{~s}$ )

Table 4

Assignment of resonances in the ${ }^{13} \mathrm{CP} / \mathrm{MAS}$ NMR and ${ }^{13} \mathrm{SP} / \mathrm{MAS}$ NMR spectra of the original beechwood, wheat straw and rice husk [79-83].

\begin{tabular}{ll}
\hline Chemical shift, ppm & Description \\
\hline $172-174$ & Carbohydrate; $-\mathrm{COO}-\mathrm{R}, \mathrm{CH}_{3}-\mathrm{COO}-$ \\
$153-154$ & Lignin; S3(e), S5(e) \\
$145-148$ & Lignin; S3(ne), S5(ne), G1(e), G4(e) \\
$133-138$ & Lignin; S1(e), S4(e), G1(e) \\
$121-122$ & Lignin; G6 \\
$105-106$ & Carbohydrates; C1, Lignin; S2, S6 \\
$89-92$ & $\mathrm{C} 4$ in cellulose (cr) \\
$84-85$ & $\mathrm{C} 4$ in cellulose (am) \\
$72-75$ & $\mathrm{C} 2$, C3 in carbohydrates; C5 in cellulose \\
$63-65$ & $\mathrm{CH}_{2}$ OH (C6 in cellulose, C5 in xylan) \\
$56-57$ & Lignin, OCH \\
$30-38$ & $\mathrm{CH}_{2}$ in aliphatics \\
21 & Carbohydrates; $\mathrm{CH}_{3}-\mathrm{COO}-$ \\
\hline
\end{tabular}

Abbreviations: S, syringyl; G, guaiacyl; ne, in non-etherified arylglycerol $\beta$-aryl ethers; e, in etherified arylglycerol $\beta$-aryl ethers.

6). The chars prepared under slow heating could be fitted by two spectra with g-values $(2.0026-2.0046)$, indicating two radical types which were assigned to oxygen-centered radicals $(\mathrm{g}=2.0038-2.0047)[12]$ and carbon-centered radicals $(\mathrm{g}=2.0025-2.003)$ based on their $\mathrm{g}$-values $[12,61,62]$.
The simulated spectra indicated two slightly different species in the wood and herbaceous chars generated by fast heating with $1 \mathrm{~s}$ holding time. These radical were most likely of a polyaromatic origin ( $\mathrm{g}=2.0029$ ) with either $1-5$ ring aromatic hydrocarbons ( $g=2.0026-2.0028)$ or carbon-centered radicals with containing oxygen [13]. When the holding time increased from 1 to $2 \mathrm{~s}$, the spectra could be described by only one type of radicals, which was proposed to consist of a complex polyaromatic structure with more than five rings like benzoperylene or coronene $(g=2.0029)$ [13]. Interestingly, only rice husk char, prepared in the wire mesh reactor with 2 s holding time, showed the presence of two types of radicals. The g-factors of hemicellulose and lignin char radicals decreased with oxygen elimination and formation of PAH structures with the stable aromatic radicals $(\mathrm{g}=2.0031)$. The remaining radicals in the hemicellulose char are most likely of a similar carbon-centered type with the negligible structural differences $(\mathrm{g}=2.0029-2.0031)$ (Table 6).

The results of the present study indicate that the free radicals in softwood and wheat straw lignin chars form more complex polyaromatic radical structures with an oxygen, corresponding to investigations of Tian et al. [23]. The wheat straw and rice husk chars, generated in the entrained flow reactor, formed aromatic radicals of a similar type as it was observed in the chars, prepared at a lower heating rate in the wire mesh reactor. 


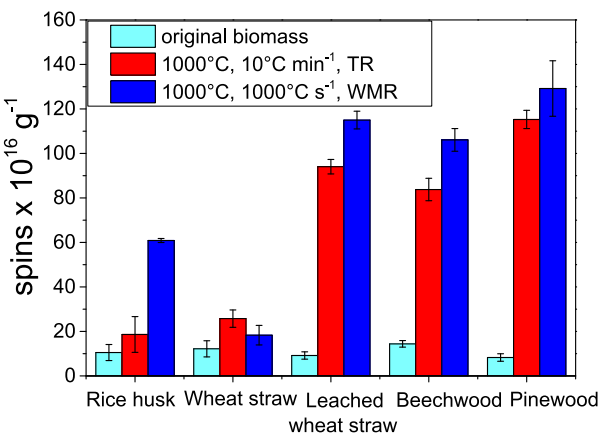

(a): Comparison of raw fuels and their chars generated in the WMR and TR

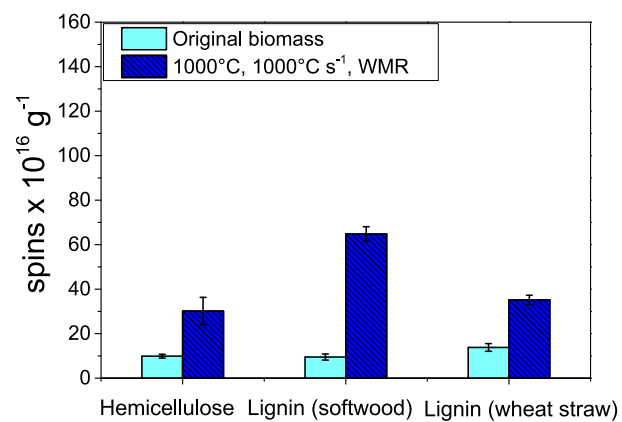

(c): Comparison of biomass compounds pyrolyzed in the WMR

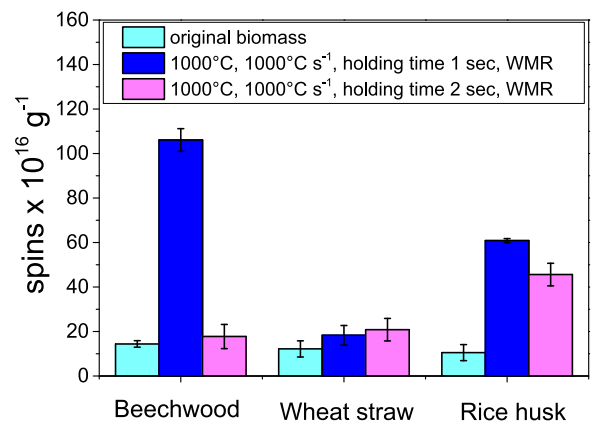

(b): Comparison of raw fuels and their chars generated at $1 \mathrm{~s}$ or $2 \mathrm{~s}$ holding time in the WMR

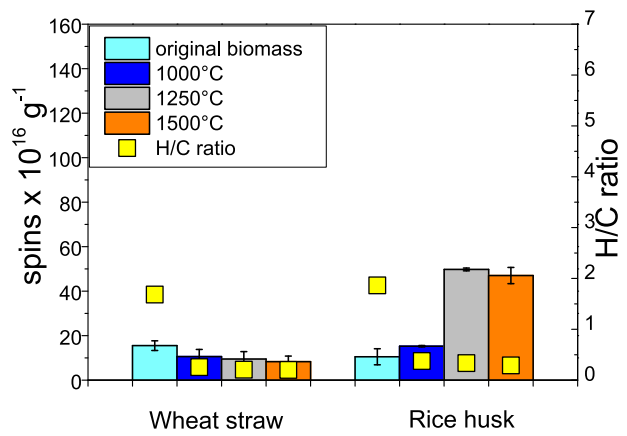

(d): Comparison of raw fuels and their chars generated in the EFR

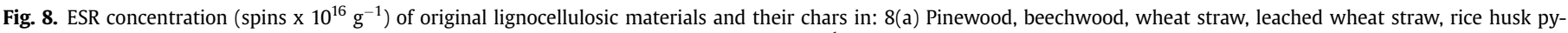

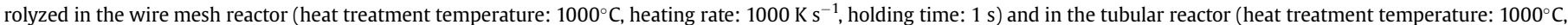

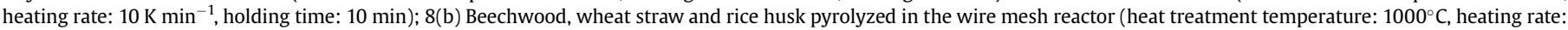

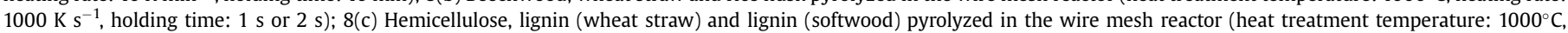

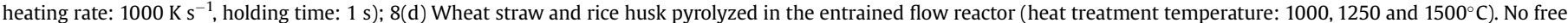
radicals were detected in the pinewood and leached wheat straw chars from the decay stage of pyrolysis in the entrained flow reactor.

\section{Discussion}

The ESR analysis was performed on the original wood, herbaceous biomass and plant cell wall compounds and their chars, prepared at different heating rates and at temperatures above $1000^{\circ} \mathrm{C}$ in the tubular, wire mesh and entrained flow reactors. The free radicals were detected by ESR in the char matrices obtained during the decay stage after pyrolysis was completed. The decay stage of pyrolysis is characterized by the radicals, which are stabilized by entrapment in the solid biomass char matrix at room temperature [23].

The wood, leached wheat straw and rice husk gave a lower char yield and higher free radical concentrations than wheat straw in the wire mesh reactor with a heating rate of $1000 \mathrm{~K} \mathrm{~s}^{-1}$ and at a temperature of $1000^{\circ} \mathrm{C}$. The high levels of carbon-centered radicals, which were detected in the chars from the decay stage, may inhibit repolymerization/cross-linking [24], and decrease the wood char yield. The cross-linking of wheat straw char prepared in the wire mesh reactor was proposed to be additionally affected by the high potassium level, leading to the higher char yield and lower radical concentrations than in wood and leached wheat straw chars. High heating rates cause a strong bond-breaking in lignocellulosic materials before it starts to cross-link and therefore becomes fluid, leading to a significant tar release. The high levels of potassium cause less severe plasticization by catalyzing the conversion of bridges into char links, and therefore increasing polymerization/ cross-linking and reducing char fluidity. The wood and leached wheat straw chars, generated in the entrained flow reactor, had no remaining free radicals, indicating an efficient recombination of radicals. The radical quenching (recombination reaction) of wood and leached wheat straw was mainly affected by the higher heating rate in the entrained flow reactor than at slow and intermediate heating rates in the tubular and wire mesh reactors. The tubular reactor at slow heating rate conditions provides a longer time of radical stabilization, and thus, longer reaction times to form nonradical products in the char matrix.

The high potassium content in the wheat straw affected catalytically the radical concentration in the char matrix. Sancier et al. [63] discussed the mechanism of potassium effect on the radical concentration in catalytic coal gasification. The high potassium levels accelerate the formation of reactive aliphatic radicals $(\mathrm{g}=2.0030)$. The formation of potassium-carbon bonds, such as in the potassium rich wheat straw, can weaken carbon-carbon bonds in aromatic rings and thereby facilitate bond breaking at high temperatures. This leads to formation of aliphatic radicals which react further to produce stable polyaromatic compounds through polymerization/cross-linking reactions at an early stage of the pyrolysis [64-67]. At temperatures of $1000-1500^{\circ} \mathrm{C}$ close to $70 \%$ 


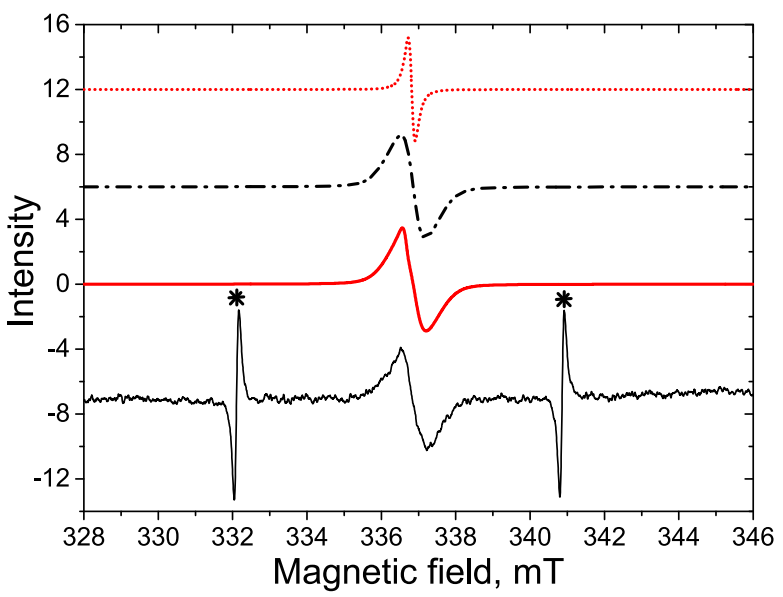

(a): ESR-spectra of original beechwood

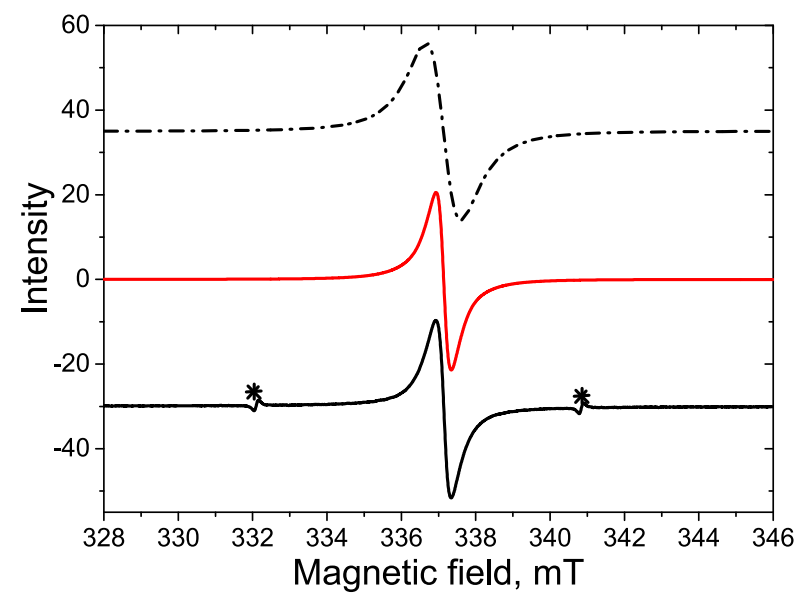

(b): ESR-spectra of rice husk char prepared in the WMR

Fig. 9. Experimental ESR-spectra of 9(a) original beechwood and 9(b) rice husk char (or PAH radical type 3 from Table 5) pyrolyzed in the wire mesh reactor $\left(1000^{\circ} \mathrm{C}\right.$, $1000 \mathrm{~K} \mathrm{~s}^{-1}, 1 \mathrm{~s}$ ) and fitted to simulated data with RMS $=0.85$ (original beechwood) and RMS $=0.999$ (rice husk char). The experimental ESR-spectra are shown (black line), the simulated spectra (red line), fitting peak 1 (red dotted line) and fitting peak 2 (black dashed line). The Mn (II) internal marker signals are marked by stars. (For interpretation of the references to colour in this figure legend, the reader is referred to the web version of this article.)

potassium in the wheat straw has been released (Fig. 5), and the remaining potassium was probably bonded to the wheat straw char in phenolate groups or intercalated in graphene layers [68], reducing the mobility of potassium in the char matrix. The higher radical concentrations in the wheat chars from the decay stage of pyrolysis in the entrained flow reactor compared to the wood chars may be related to the decreased mobility of potassium in the char matrix, leading to the less efficient catalytic effects of potassium on the bond-breaking and radical re-attachments.

The increased radical concentrations in the rice husk chars, generated in the entrained flow reactor, were caused by the formation of carbon-centered radicals. The rice husk sample contains high concentrations of silicon that is present as silicon oxides with small amounts of alkalis and other trace elements. Lanning [69] concluded that silicon occurs in rice husk in a hydrated amorphous form (opal or silica gel), located mainly in the outer epidermis and filling the inner channels in the spiral structure of the epidermal cells. In addition, Liu et al. [70] and Sharma et al. [71] proposed that the silica in the rice husk is combined with

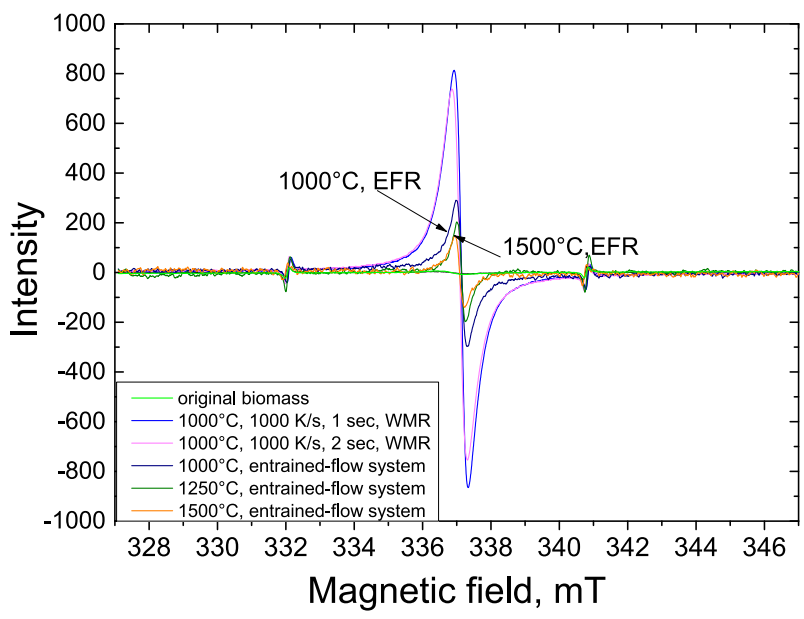

(a): ESR-spectra of rice husk

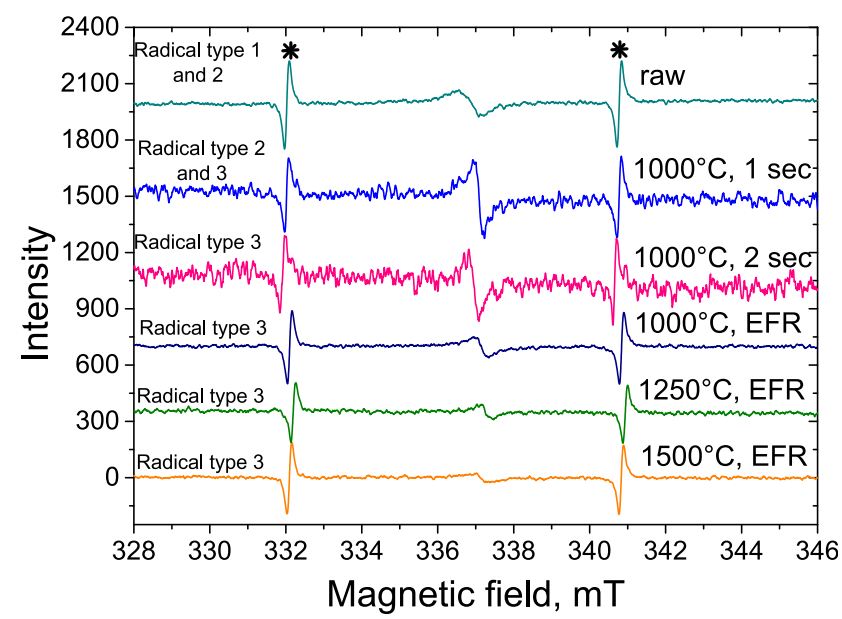

(b): ESR-spectra of wheat straw

Fig. 10. ESR-spectra of 10 (a) rice husk (raw $(\mathrm{RMS}=0.86)$ and their chars prepared in the entrained flow reactor at $1000^{\circ} \mathrm{C}(\mathrm{RMS}=0.94)$, at $1250^{\circ} \mathrm{C}(\mathrm{RMS}=0.85)$, at $1500^{\circ} \mathrm{C}$ (RMS $=0.959)$, and in the wire mesh reactor at $\left(1000^{\circ} \mathrm{C}, 1000 \mathrm{~K} \mathrm{~s}^{-1}, 1 \mathrm{~s}\right.$ or $2 \mathrm{~s}$ $(\mathrm{RMS}=0.999))) ; 10(\mathrm{~b})$ wheat straw $($ raw $(\mathrm{RMS}=0.85)$ and their chars prepared in the entrained flow reactor at $1000^{\circ} \mathrm{C}(\mathrm{RMS}=0.85)$, at $1250^{\circ} \mathrm{C}(\mathrm{RMS}=0.86)$, at $1500^{\circ} \mathrm{C}$ $($ RMS $=0.87)$, and in the wire mesh reactor $\left(1000^{\circ} \mathrm{C}, 1000 \mathrm{~K} \mathrm{~s}^{-1}, 1 \mathrm{~s}\right.$ or $2 \mathrm{~s}$ $(\mathrm{RMS}=0.87)$ ). The Mn (II) internal marker signals are marked by stars.

carbohydrates. In the present study, the ash compositional analysis showed that the elemental silicon content in the rice husk chars generated in the entrained flow reactor remained unchanged (Fig. 5). The radicals formed at rapid heating rates were proposed to be trapped upon fast cooling in a glassy char structure composed of an amorphous silica phase (glass transition temperature $\approx 730^{\circ} \mathrm{C}$ ) [72]. Trapping of organic radicals in amorphous silicon has been reported by Friebele et al. [73], who detected methyl radicals in a heat-treated synthetic silicon fused in a hydrogen-oxygen flame.

Two types of free radicals were identified by fitting the ESRspectra to the simulated data. Biomass chars, generated at different operational conditions, showed almost negligible differences in the radical structure. The original lignocellulosic materials contained mostly oxygen-centered radicals, whereas at high temperatures aliphatic carbon-centered radicals ( $\mathrm{g}=2.0026-2.0028$ ) and PAH radicals ( $\mathrm{g}=2.0027-2.0035)$ were formed during pyrolysis in the wire mesh and entrained flow reactors. The decreased experimental sensitivity of ${ }^{13} \mathrm{C} \mathrm{CP} / \mathrm{MAS}$ and ${ }^{13} \mathrm{C}$ SP/MAS NMR 
Table 5

Simulation results of original biomass and chars prepared in the wire mesh and tubular reactors.

\begin{tabular}{|c|c|c|c|c|c|}
\hline Biomass & Reactor/holding time & Heating rate & Area, \% & g-factor & Line width (Gauss) \\
\hline \multirow{6}{*}{ Pinewood } & \multirow{2}{*}{ Original biomass } & & 72 & 2.0052 & 5.9 \\
\hline & & & 28 & 2.0033 & 4.3 \\
\hline & \multirow{2}{*}{ Tubular reactor } & \multirow{2}{*}{$10 \mathrm{~K} \mathrm{~min}^{-1}$} & 94.9 & 2.0028 & 5.2 \\
\hline & & & 5.2 & 2.0034 & 4.1 \\
\hline & \multirow{2}{*}{ Wire mesh reactor, $1 \mathrm{~s}$} & \multirow{2}{*}{$1000 \mathrm{~K} \mathrm{~s}^{-1}$} & 54.5 & 2.0030 & 4.3 \\
\hline & & & 45.5 & 2.0029 & 5.1 \\
\hline \multirow{7}{*}{ Beechwood } & \multirow{2}{*}{ Original biomass } & & 5.9 & 2.0031 & 2.2 \\
\hline & & & 94.1 & 2.0048 & 4.7 \\
\hline & \multirow{2}{*}{ Tubular reactor } & \multirow{2}{*}{$10 \mathrm{~K} \mathrm{~min}^{-1}$} & 17.3 & 2.0030 & 5 \\
\hline & & & 82.7 & 2.0039 & 4 \\
\hline & \multirow{2}{*}{ Wire mesh reactor, $1 \mathrm{~s}$} & \multirow{2}{*}{$1000 \mathrm{~K} \mathrm{~s}^{-1}$} & 21.8 & 2.0035 & 2.9 \\
\hline & & & 78.2 & 2.0028 & 4.1 \\
\hline & Wire mesh reactor, $2 \mathrm{~s}$ & $1000 \mathrm{~K} \mathrm{~s}^{-1}$ & 100 & 2.0031 & 4.3 \\
\hline \multirow{6}{*}{ Wheat straw } & \multirow{2}{*}{ Original biomass } & \multirow{4}{*}{$10 \mathrm{~K} \mathrm{~min}^{-1}$} & 86.5 & 2.0050 & 5.1 \\
\hline & & & 13.5 & 2.0035 & 3.4 \\
\hline & \multirow{2}{*}{ Tubular reactor } & & 17.6 & 2.0033 & 4 \\
\hline & & & 82.4 & 2.0026 & 5.6 \\
\hline & Wire mesh reactor, $1 \mathrm{~s}$ & $1000 \mathrm{~K} \mathrm{~s}^{-1}$ & 100 & 2.0031 & 2.5 \\
\hline & Wire mesh reactor, $2 \mathrm{~s}$ & $1000 \mathrm{~K} \mathrm{~s}^{-1}$ & 100 & 2.0027 & 2.3 \\
\hline \multirow{4}{*}{ Leached wheat straw } & \multirow{2}{*}{ Original biomass } & & 66 & 2.0046 & 5.1 \\
\hline & & & 34 & 2.0033 & 3.5 \\
\hline & Tubular reactor & $10 \mathrm{~K} \mathrm{~min}^{-1}$ & 100 & 2.0030 & 4.4 \\
\hline & Wire mesh reactor, $1 \mathrm{~s}$ & $1000 \mathrm{~K} \mathrm{~s}^{-1}$ & 100 & 2.0029 & 3.8 \\
\hline \multirow{6}{*}{ Rice husk } & \multirow{2}{*}{ Original biomass } & & 98.4 & 2.0043 & 7.1 \\
\hline & & & 1.6 & 2.0027 & 1.7 \\
\hline & \multirow{2}{*}{ Tubular reactor } & \multirow{2}{*}{$10 \mathrm{~K} \mathrm{~min}^{-1}$} & 27.7 & 2.0026 & 2.5 \\
\hline & & & 72.3 & 2.0046 & 7.1 \\
\hline & Wire mesh reactor, $1 \mathrm{~s}$ & $1000 \mathrm{~K} \mathrm{~s}^{-1}$ & 100 & 2.0030 & 7.5 \\
\hline & Wire mesh reactor, $2 \mathrm{~s}$ & $1000 \mathrm{~K} \mathrm{~s}^{-1}$ & 100 & 2.0028 & 9.8 \\
\hline
\end{tabular}

Table 6

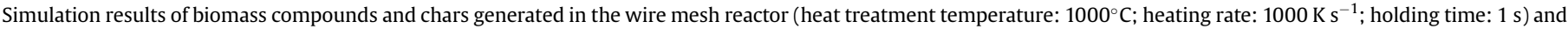
wheat straw and rice husk chars generated in the entrained flow reactor (heat treatment temperatures: 1000,1250 and $1500^{\circ} \mathrm{C}$ ).

\begin{tabular}{|c|c|c|c|c|}
\hline Biomass & Condition & Area, \% & g-factor & Line width (Gauss) \\
\hline \multirow[t]{2}{*}{ Hemicellulose } & Original compound & 100 & 2.0047 & 5.8 \\
\hline & Wire mesh reactor, $1 \mathrm{~s}, 1000 \mathrm{~K} \mathrm{~s}^{-1}$ & 100 & 2.0030 & 5 \\
\hline \multirow[t]{2}{*}{ Lignin (softwood) } & Original compound & 100 & 2.0037 & 5 \\
\hline & Wire mesh reactor, $1 \mathrm{~s}, 1000 \mathrm{~K} \mathrm{~s}^{-1}$ & 100 & 2.0029 & 4.3 \\
\hline \multirow[t]{3}{*}{ Lignin (straw) } & Original compound & 100 & 2.0046 & 4.2 \\
\hline & & 26.1 & 2.0028 & 3 \\
\hline & Wire mesh reactor, $1 \mathrm{~s}, 1000 \mathrm{~K} \mathrm{~s}$ & 73.9 & 2.0034 & 4.3 \\
\hline \multirow[t]{5}{*}{ Wheat straw } & & 86.5 & 2.0050 & 5.1 \\
\hline & Original biomass & 13.5 & 2.0035 & 3.4 \\
\hline & Entrained flow reactor, $1000^{\circ} \mathrm{C}$ & 100 & 2.0028 & 3.1 \\
\hline & Entrained flow reactor, $1250^{\circ} \mathrm{C}$ & 100 & 2.0030 & 2.8 \\
\hline & Entrained flow reactor, $1500^{\circ} \mathrm{C}$ & 100 & 2.0029 & 2.9 \\
\hline \multirow[t]{5}{*}{ Rice husk } & & 98.4 & 2.0043 & 7.1 \\
\hline & Original biomass & 1.6 & 2.0027 & 1.7 \\
\hline & Entrained flow reactor, $1000^{\circ} \mathrm{C}$ & 100 & 2.0032 & 15.8 \\
\hline & Entrained flow reactor, $1250^{\circ} \mathrm{C}$ & 100 & 2.0031 & 10.1 \\
\hline & Entrianed flow reactor, $1500^{\circ} \mathrm{C}$ & 100 & 2.0030 & 7.8 \\
\hline
\end{tabular}

analysis was caused by the isolated free radicals in the carbonaceous bulk as it was proposed by Bardet et al. [74].

The heating rate and heat treatment temperature affected the dominating ESR signal shape less than the high Si mass fraction in the rice husk that caused an ESR line broadening $(\approx 7.1 \mathrm{G})$ in the pyrolysis. Moreover, the fitting of ESR-spectra to the simulated data showed that the line width of ESR-spectra remained between 4 and $6 \mathrm{G}$ for the wood chars independent on the heating rate and holding time, whereas the herbaceous biomass chars obtained a narrow line width $(2.3$ and $3.4 \mathrm{G})$ and broad line width (4 and $7.1 \mathrm{G}$ ) which did not change significantly during pyrolysis. Both line types were narrower than the line widths of radicals obtained for carbon black (23-66 G) [75]. The ESR signal of pyrolyzed lignocellulosic materials is often only a broad featureless singlet without the hyperfine splitting which is caused by the presence of multiple radical species or strong matrix interaction occurred between the products [76]. In addition, the heterogeneity of biomass samples and that the radicals are not exclusively centered on single atoms could lead to broad featureless singlets, as reported by Herring et al. [76]. Investigations of Ross et al. [77] showed that the differences in line widths were caused by the formation of the disorganized carbon with unpaired electrons (narrow signal) and organized carbon with the conductive electrons (broad signal). In the present study, the line broadening of rice husk chars was associated with the radicals of carbon-centered type, encapsulated in the chars due to the amorphous silicon melting at high temperatures. 


\section{Conclusion}

High concentrations of free radicals were detected by ESR in wood and herbaceous chars from the decay stage of pyrolysis at slow and fast heating rates and at temperatures above $1000^{\circ} \mathrm{C}$. The free radicals in the lignocellulosic chars from the decay stage of pyrolysis were stable at room temperature and showed similar structural characteristics. The radical concentrations ranged up between $7 \cdot 10^{16}$ and $1.5 \cdot 10^{18}$ spins $\mathrm{g}^{-1}$. The results showed that the radicals in wood and herbaceous biomass chars were mainly aliphatic and $\mathrm{PAH}$ radicals, whereas the original lignocellulosic materials contained mainly oxygen-centered radicals. The ESR spectra of radicals showed the narrower line widths of $<6 \mathrm{G}$. The gfactors (2.0026-2.0030) in the chars from the decay stage of pyrolysis were attributed to $\pi$-hydrocarbon radicals, embedded in larger polycyclic aromatic hydrocarbon structures of biomass chars.

Similar radical concentrations were detected by ESR in the chars generated in the wire mesh reactor from pinewood, beechwood and leached wheat straw. The original lignocellulosic materials showed differences in the distribution among the three major biomass constituents (cellulose, hemicellulose, lignin), whereas the alkali content was similarly low compared to rice husk and wheat straw. The results indicate that the biomass major constituents had a minor effect on remaining radical concentrations compared to potassium and silica contents.

Potassium was proposed to catalyze the reaction between radicals forming larger and stable structures. The higher radical concentrations in the wheat straw chars from the decay stage of pyrolysis in the entrained flow reactor compared to the wood chars were related to the decreased mobility of potassium in the char matrix, leading to the less efficient catalytic effects of potassium on the bond-breaking and radical re-attachments. The high levels of radicals in the rice husk chars generated in the wire mesh and entrained flow reactors were related to the trapping of free radicals in a molten Si-rich char with increasing temperature, and followed by the rapid cooling in the reactors.

\section{Acknowledgements}

The authors would like to acknowledge the financial support that they received for this project from Danish Strategic Research Council (Grant Nr. DSF-10-093956), DONG Energy and Vattenfall. We also thank Professor Spliethoff and Markus Steibel (TU Munich) for the support with the entrained flow reactor experiments, Jesper Harholt (Carlsberg Laboratory) and Søren Talbro Barsberg (University of Copenhagen, Department of Geosciences and Natural Resource Management) for assisting with the biomass compositional analysis and for the fruitful discussions.

\section{References}

[1] O. Edenhofer, R. Madruga, Y. Sokona, J. Minx, E. Farahani, S. Kadner, et al., Climate change 2014: mitigation of climate change, in: Working Group III Contribution to the IPCC Fifth Assessment Report, Cambridge University Press, 2015.

[2] B. Monsen, M. Tangstad, H. Midtgaard, Use of charcoal in silicomanganese production, in: Tenth International Ferroalloys Congress INFACON X vol. 68, Transformation through Technology, 2004, pp. 155-164.

[3] J.G. Mathieson, H. Rogers, M.A. Somerville, S. Jahanshahi, P. Ridgeway, Potential for the use of biomass in the iron and steel industry, in: Chemeca 2011. Engineering a Better World, Australia, 18-21 September, 2011, pp. 1-12.

[4] J. Amonette, S. Joseph, Characteristics of biochar: microchemical properties, in: J. Lehmann (Ed.), Biochar for Environmental Management, Earthscan, 2009.

[5] M.Y. Zhau, A. Enders, J. Lehmann, Short- and long-term flammability of biochars, Biomass Bioenergy 69 (2014) 183-191.

[6] R. Brown, Biochar production technology, in: J. Lehmann (Ed.), Biochar for Environmental Management, Earthscan, 2009.

[7] J. Bourke, M. Manley-Harris, C. Fushimi, K. Dowaki, T. Nunoura, M.J. Antal, Do all charcoals have the same chemical structure? 2. A model of the chemical structure of carbonized charcoal, Ind. Eng. Chem. Res. 46 (18) (2007) 5954-5967.

[8] S. Liao, B. Pan, H. Li, D. Zhang, B. Xing, Detecting free radicals in biochars and determining their ability to inhibit the germination and growth of corn, wheat and rice seedlings, Environ. Sci. Tech. 48 (2014) 8581-8587.

[9] X.Y. Zhou, F. Zheng, C.L. Lv, L.J. Tang, K.C. Wei, Liu XY, et al., Properties of formaldehyde-free environmentally friendly lignocellulosic composites made from poplar fibres and oxygen-plasma-treated enzymatic hydrolysis lignin, Compos. Part B Eng. 53 (2013) 369-375.

[10] J. Uebersfeld, A. Etienne, J. Combrisson, Paramagnetic resonance. A new property of coal-like materials, Nature 174 (4430) (1954) 614.

[11] D.J.E. Ingram, J.G. Tapley, R. Jackson, R.L. Bond, A.R. Murnaghan, Paramagnetic resonance in carbonaceous solids, Nature 174 (4434) (1954) 797.

[12] L. Petrakis, D.W. Grandy, Electron spin resonance spectrometric study of free radicals on coals, Anal. Chem. 50 (2) (1978) 303-308.

[13] I.C. Lewis, L.S. Singer, Electron spin resonance and the mechanism of carbonization, Chem. Phys. Carbon 17 (1981) 1-88.

[14] T. Urbanski, S. Benbenek, S. Bedynski, A. Wasilewski, Free radicals in charcoal and the combustion of compositions containing charcoal, Explosivstoffe 1 (1970) 9-11.

[15] A.J. Nanassy, A. Vyas, Electron spin resonance in pyrolyzed lignin, J. Macromol Sci. Phys. B 3 (2) (1969) 271-292.

[16] Z. Maskos, L. Khachatryan, R. Cueto, W.A. Pryor, B. Dellinger, Radicals from the pyrolysis of tobacco, Energy Fuels 19 (3) (2005) 791-799.

[17] J. Jamil, J. Hayashi, C.Z. Li, Pyrolysis of a victorian brown coal in helium and $\mathrm{CO}_{2}$ Atmosphere, J. Energy Environ. 4 (2005) 83-96.

[18] M.R. Schurr, R. Hayes, L.L. Bush, The thermal history of maize kernels determined by electron spin resonance, Archaeometry 43 (3) (2001) 407-419.

[19] I. Cohen-Ofri, L. Weiner, E. Boaretto, G. Mintz, S. Weiner, Modern and fossi charcoal: aspects of structure and diagenesis, J. Arch. Sci. 33 (3) (2006) 428-439.

[20] R. Khan, J. Chu, J. Margrave, R. Hauge, R. Smalley, Free radical chemistry during slow pyrolysis of solid fuels, Energy Sources 27 (3) (2005) 309-318.

[21] H.L. Retcofsky, G.P. Thompson, M. Hough, R.A. Friedel, Electron spin resonance studies of coals and coal-derived asphaltenes, 174th Symp Org Chem Coal, Am Chem Soc Natl Meet 22 (5) (1977) 90-97.

[22] H.L. Retcofsky, M. Hough, R.B. Clarkson, Nature of the free radicals in coals, pyrolyzed coals, and liquefaction products, ACS Fuel Chem. 24 (1) (1979) 83-89.

[23] L. Tian, C.P. Koshland, J. Yano, V.K. Yachandra, I.T.S. Yu, S.C. Lee, et al., Carboncentered free radicals in particulate matter emissions from wood and coal combustion, Energy Fuels 23 (5) (2009) 2523-2526.

[24] C.M. Blanchard, M.R. Gray, Free radical chain reactions of bitumen residue ACS Div. Fuel Chem. 42 (1) (1997) 137-141.

[25] A.I. Afifi, J.P. Hindermann, E. Chornet, R.P. Overend, The cleavage of the aryl-o$\mathrm{CH}_{3}$ bond using anisole as a model-compound, Fuel 68 (4) (1989) 498-504.

[26] J.W. Feng, S. Zheng, G.E. Maciel, EPR investigations of charring and char/air interaction of cellulose, pectin, and tobacco, Energy Fuels 18 (2004) 560-568.

[27] W.H. Wiser, G.R. Hill, N.J. Kertamus, Kinetic study of pyrolysis of a highvolatile bituminous coal, Ind. Eng. Chem. 6 (1) (1967) 133-138.

[28] E.A. Shapatina, V.V. Kalyuzhnyi, Z.R. Chukhanov, Rate of evolution of volatile substances in the thermal decomposition of the organic mass of coal, Dokl. Akad. Nauk. SSSR 72 (1950) 869-872.

[29] D. Fitzgerald, Kinetic study of coal carbonization in the plastic zone, Fuel 35 (2) (1956) 178-183.

[30] T.G. Fowler, K.D. Bartle, R. Kandiyoti, Limitations of electron spin resonance spectroscopy in assessing the role of free radicals in the thermal reactions of coal, Explosivstoffe 3 (4) (1989) 515-522.

[31] T. Yokono, N. Oka, Y. Sanada, T. Obara, Stability test of SRC II distillates by ESR, Liq. Fuels Technol. 1 (3) (1983) 199-204.

[32] Y. Yamada, A. Matsumura, T. Kondo, K. Ukegawa, E. Nakamura, Free radicals formed in hydrotreated coal liquid and influence of oxygen, Pet. Sci. Technol. 2 (2) (1984) 165-176.

[33] R. Usmen, R. Khan, Role of free radical chemistry on oxidative stability of coal pyrolysis liquids, Fuel Process Technol. 22 (2) (1989) 151-158.

[34] W. He, Q. Liu, L. Shi, D. Ci, C. Lievens, X. Guo, et al., Understanding the stability of pyrolysis tars from biomass in a view point of free radicals, Bioresour. Technol. 156 (2014) 372-375.

[35] J. Kihedu, Fundamental Study on Co-gasification of Biomass with Coal (PhD thesis), Nagoya University, 2013.

[36] A. Tremel, H. Spliethoff, Gasification kinetics during entrained flow gasification - Part I; devolatilisation and char deactivation, Fuel 103 (2013) 663-671.

[37] E. Hoekstra, W.P.M. van Swaaij, S.R.A. Kersten, K.J.A. Hogendoorn, Fast pyrolysis in a novel wire mesh reactor: design and initial results, Chem. Eng. J. 191 (2012) 45-58.

[38] A. Tremel, T. Haselsteiner, C. Kunze, H. Spliethoff, Experimental investigation of high temperature and high pressure coal gasification, Appl. Energy 92 (2012) 279-285.

[39] A. Tremel, Reaction Kinetics of Solid Fuels during Entrained Flow Gasification (PhD thesis), TU Munich, 2012.

[40] Damoe A.J., Frandsen F.J., Jensen P.A., Wu H., Glarborg P., Residual Ash Formation during suspension-firing of biomass. Effects of Residence Time and Fuel Type, Proc Impacts Fuel Qual; 2014 Oct 26th-31rd, Snowbird, UT, US 627-648.

[41] K. Werner, L. Pommer, M. Brostrm, Thermal decomposition of hemicelluloses 
J. Anal. Appl. Pyrolysis 110 (2014) 130-137.

[42] A. Sluiter, B. Hames, R. Ruiz, C. Scarlata, J. Sluiter, D. Templeton, et al Determination of Structural Carbohydrates and Lignin in Biomass, Golden (CO): National Renewable Energy Laboratory, 2011 July. Report No. NREL/TP510-42618. Contract No.: DE-AC36-08-G028308.

[43] S. Willför, J. Hemming, A.S. Leppänen, Analysis of Extractives in Differen Pulps - Method Development, Evaluation, and Recommendations, Åbo Akademi University, Laboratory of Wood and Paper Chemistry, Finland, 2004 2009. Report No. B1 of the EU COST E41 action "Analytical tools with applications for wood and pulping chemistry".

[44] B. Hames, R. Ruiz, C. Scarlata, J. Sluiter, A. Sluiter, Preparation of Samples for Compositional Analysis, Golden (CO): National Renewable Energy Laboratory, 2011 June. Report No. NREL/TP-510-42620. Contract No.: DE-AC36-99G010337.

[45] K. Thammasouk, D. Tandjo, M.H. Penner, Influence of extractives on the analysis of herbaceous biomass, J. Agric. Food Chem. 45 (2) (1997) 437-443.

[46] G.L. Borman, K.W. Ragland, Combustion Engineering, McGraw-Hill, 1998.

[47] O.B. Peersen, X. Wu, I. Kustanovich, S.O. Smith, Variable-amplitude crosspolarization MAS NMR, J. Magn. Reson Ser. A 104 (1993) 334-339.

[48] A.E. Bennett, C.M. Rienstra, M. Auger, K.V. Lakshmi, R.G. Griffin, Heteronuclear decoupling in rotating solids, J. Chem. Phys. 103 (16) (1995) 6951-6958.

[49] L.D.S. Yadav, Organic Spectroscopy, Springer, 2005.

[50] F. Gerson, W. Huber, Electron Spin Resonance Spectroscopy of Organic Radicals, Wiley-VCH, 2003.

[51] D.R. Duling, Simulation of multiple isotropic spin-trap EPR spectra, J. Magn. Reson. Ser. B 104 (2) (1993) 105-110.

[52] A. Trubetskaya, A.D. Jensen, M. Steibel, H. Spliethoff, P.A. Jensen, P. Glarborg, Influence of fast pyrolysis conditions on yield and structural transformation of biomass chars, Fuel Process Tech. 140 (2015) 205-214.

[53] J.N. Knudsen, P.A. Jensen, K. Dam-Johansen, Transformation and release to the gas phase of $\mathrm{Cl}, \mathrm{K}$ and $\mathrm{S}$ during combustion of annual biomass, Energy Fuels 18 (5) (2004) 1385-1399.

[54] I. Bertini, P. Turano, A.J. Vila, Nuclear magnetic resonance of paramagnetic metalloproteins, Chem. Rev. 93 (8) (1993) 2833-2932.

[55] J.C.C. Freitas, F.G. Emmerich, T.J. Bonagamba, High-resolution solid-state NMR study of the occurrence and thermal transformations of silicon-containing species in biomass materials, Chem. Mater. 12 (3) (2000) 711-718.

[56] H. Sivonen, S.L. Maunu, F. Sundholm, S. Jamsa, P. Viitaniemi, Magnetic resonance studies of thermally modified wood, Holzforschung 56 (2002) 648-654.

[57] C. Steelink, G. Tollin, Stable free radicals in soil humic acid, Biochim. Biophys. Acta 59 (1962) 25-34.

[58] R.W. Rex, Electron paramagnetic resonance studies of stable free radicals in lignins and humic acids, Nature 188 (1960) 1185-1186.

[59] K.H. Kim, Understanding the Thermochemical Conversion of Biomass to Overcome Biomass Recalcitrance (PhD thesis), Iowa State University, 2015.

[60] D.L. Tuck, D.W. Schieser, Electron spin resonance of some nitrogen-containing aromatic free radicals, J. Phys. Chem. 66 (1962) 937-939.

[61] U. Green, Z. Aizenshtat, S. Ruthstein, H. Cohen, Reducing the spin-spin interaction of stable carbon radicals, Phys. Chem. Chem. Phys. 15 (17) (2013) 6182-6184.

[62] P. Delhaes, A. Marchand, Analysis of the form and position of EPR lines observed in powdered graphitic carbons, Carbon 6 (2) (1968) 257-266.

[63] B.J. Wood, K.M. Sancier, D.R. Sheridan, B.L. Chan, H. Wise, The Mechanism of Catalytic Gasification of Coal Char, Morgantown (WV): US Department of Energy, 1981 December. Report No. DE82-009461. Contract No.: DE-AC2180-MC14593.
[64] J.W. Gilman, S. Lomakin, T. Kashiwagi, D.L. Vanderhart, V. Nagy, Characterization of flame-retarded polymer combustion chars by solid-state ${ }^{13} \mathrm{C}$ and ${ }^{29}$ Si NMR and EPR, Fire Mater. 22 (1998) 61-67.

[65] K.M. Sancier, Effects of catalysts and $\mathrm{CO}_{2}$ Gasification on the ESR of carbon black II, Prepr. Pap. ACS Div. Fuel Chem. 28 (1983) 62-70.

[66] D.A.E. Butt, Formation of phenols from the low-temperature fast pyrolysis of radiata pine (Pinus radiata) - Part I. Influence of molecular oxygen, J. Anal. Appl. Pyrolysis 76 (2006) 38-47.

[67] H. Marsh, The effects of impregnation of coal by alkali salts upon carbonization properties, Fuel Process Tech. 2 (1979) 61-75.

[68] Y.W. Wen, Mechanisms of alkali metal catalysis in the gasification of coal, char, or graphite, Cat. Rev. Sci. Eng. 22 (1980) 1-28.

[69] F.C. Lanning, Silicon in rice, J. Agric. Food Chem. 11 (1963) 435-437.

[70] S.L. Liu, C.H. Ho, Study in the nature of silicon in rice hull. I. Solubility of the silicon part, J. Chin. Chem. Soc. 6 (1960) 141-153.

[71] R.K. Sharma, J.B. Wooten, V.L. Baliga, X. Lin, G. Chan, M.R. Hajaligol, Characterization of char from the pyrolysis of tobacco, J. Agric. Food Chem. 50 (2002) $771-783$.

[72] A. Hedler, S.L. Klaumünzer, W. Wesch, Amorphous silicon exhibits a glass transition, Nat. Mater. 3 (2004) 804-809.

[73] E.J. Friebele, D.L. Griscom, K. Rau, Observation of the methyl radical $\mathrm{CH}_{3}$; in irradiated, high-purity synthetic fused silica, J. Non Cryst Solids 57 (1983) $167-175$.

[74] M. Bardet, S. Hediger, G. Gerbaud, S. Gambarelli, J.F. Jacquot, M.F. Foray, et al., Investigation with ${ }^{13} \mathrm{C}$ NMR, EPR and magnetic susceptibility measurements of char residues obtained by pyrolysis of biomass, Fuel 86 (12-13) (2007) 1966-1976.

[75] J.R. Harbour, M.J. Walzak, Effect of electroreduction on the EPR spectra due to charge carriers in carbon blacks, Carbon 23 (1985) 687-690.

[76] P. Herring, L. Khachatryan, S. Lomnicki, B. Dellinger, Paramagnetic centers in particulate formed from the oxidative pyrolysis of 1-methylnaphthalene in the presence of $\mathrm{Fe}(\mathrm{III})_{2} \mathrm{O}_{3}$ nanoparticles, Combust. Flame 160 (2013) 2996-3003.

[77] M.M. Ross, M.R. Chedekel, T.H. Risby, S.S. Lestz, R.E. Yasbin, Electron paramagnetic resonance spectrometry of diesel particulate matter, Environ. Int. 7 (1982) 325-329.

[78] L.R.C. Barclay, M.R. Vinqvist, Membrane peroxidation - inhibiting effects of water-soluble antioxidants on phospholipids of different charge types, Free Radic. Biol. Med. 16 (1994) 779-788.

[79] M. Bardet, G. Gerbaud, M. Giffard, C. Doan, S. Hediger, L.L. Pape, ${ }^{13} \mathrm{C}$ highresolution solid-state NMR for structural elucidation of archaeological woods, Prog. Nucl. Magn. Reson. Spectrosc. 55 (2009) 199-214.

[80] M. Bardet, S. Maron, M.F. Foray, M. Berger, A. Guillermo, Investigation of $\gamma$ irradiated vegetable seeds with high-resolution solid-state ${ }^{13} \mathrm{C}$ NMR, Radiat. Res. 161 (2004) 458-463.

[81] F. Xu, J.X. Sun, R. Sun, P. Fowler, M. Baird, Comparative study of organosolv lignins from wheat straw, Ind. Crops Prod. 23 (2006) 180-193.

[82] E.A. Webster, J.A. Chudek, D.W. Hopkins, ${ }^{13} \mathrm{C}$ high-resolution solid-state NMR for structural elucidation of archaeological woods, Soil Biol. Biochem. 32 (2000) 301-314.

[83] D.G. Reid, S.L. Bonnet, G. Kemp, J.H. van der Westhuizen, Analysis of commercial proanthocyanidins. Part 4: Solid state ${ }^{13} \mathrm{C}$ NMR as a tool for in situ analysis of proanthocyanidin tannins, in heartwood and bark of quebracho and acacia, and related species, Photochemistry 94 (2013) 243-248.

[84] A. Trubetskaya, P.A. Jensen, M. Steibel, H. Spliethoff, A.D. Jensen, F. Hofmann Larsen, et al., Comparison of high temperature chars of wheat straw and rice husk with respect to chemistry, morphology and reactivity, Biomass Bioenergy 86 (2016) 76-87. 